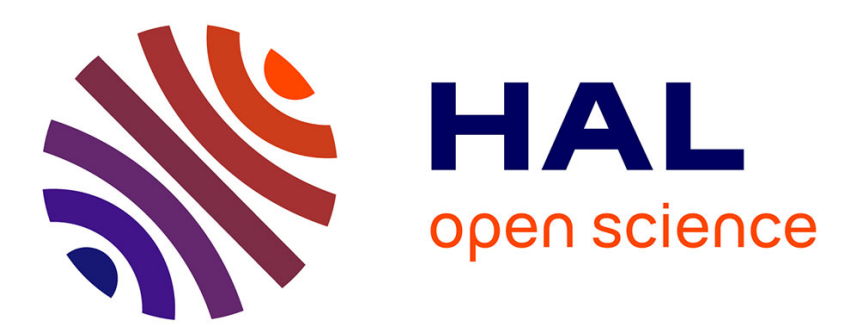

\title{
Extending the hydrogen-bonding array in ortho-phenylenediamine based bis-ureas
}

Philip Alan Gale, Simon Brooks, Mark Light

\section{To cite this version:}

Philip Alan Gale, Simon Brooks, Mark Light. Extending the hydrogen-bonding array in ortho-phenylenediamine based bis-ureas. Supramolecular Chemistry, 2007, 19 (01-02), pp.9-15. 10.1080/10610270600879076 . hal-00513484

\section{HAL Id: hal-00513484 \\ https://hal.science/hal-00513484}

Submitted on 1 Sep 2010

HAL is a multi-disciplinary open access archive for the deposit and dissemination of scientific research documents, whether they are published or not. The documents may come from teaching and research institutions in France or abroad, or from public or private research centers.
L'archive ouverte pluridisciplinaire HAL, est destinée au dépôt et à la diffusion de documents scientifiques de niveau recherche, publiés ou non, émanant des établissements d'enseignement et de recherche français ou étrangers, des laboratoires publics ou privés. 


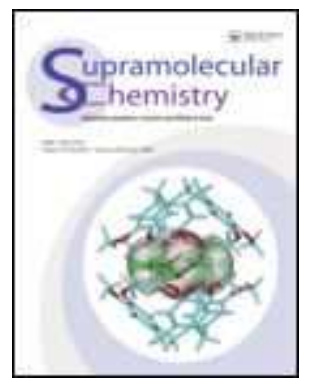

\section{Extending the hydrogen-bonding array in ortho- phenylenediamine based bis-ureas}

\begin{tabular}{|c|c|}
\hline Journal: & Supramolecular Chemistry \\
\hline Manuscript ID: & GSCH-2006-0022.R1 \\
\hline Manuscript Type: & Special Issue Paper \\
\hline $\begin{array}{l}\text { Date Submitted by the } \\
\text { Author: }\end{array}$ & 08-Jun-2006 \\
\hline Complete List of Authors: & $\begin{array}{l}\text { Gale, Philip; University of Southampton, School of Chemistry } \\
\text { Brooks, Simon; University of Southampton } \\
\text { Light, Mark; University of Southampton }\end{array}$ \\
\hline Keywords: & Anion receptors, amides, ureas, crystallography \\
\hline \multicolumn{2}{|c|}{$\begin{array}{l}\text { Note: The following files were submitted by the author for peer review, but cannot be converted } \\
\text { to PDF. You must view these files (e.g. movies) online. }\end{array}$} \\
\hline $\begin{array}{l}\text { Figure 4.cdx } \\
\text { Figure5.cdx } \\
\text { Structure of } 1 . c d x \\
\text { Scheme1.cdx } \\
\text { Scheme2.cdx }\end{array}$ & \\
\hline
\end{tabular}

\section{S ScholarONE" \\ Manuscript Central}




\title{
FOR ISSC/ISMC SPECIAL ISSUE
}

\author{
Extending the hydrogen-bonding array in ortho-phenylenediamine based \\ bis-ureas
}

Simon J. Brooks, Philip A. Gale*, and Mark E. Light

School of Chemistry, University of Southampton, Southampton, SO17 1BJ, UK.

\begin{abstract}
Two new ortho-phenylenediamine based bis-urea compounds have been synthesised with pendant amide groups. The stability constants of the new compounds with a variety of anionic guests have been measured by ${ }^{1} \mathrm{H}$ NMR titration techniques and compared to the parent bis-urea. The X-ray crystal structure of the acetate and benzoate complexes of a bis-amide functionalised system have been solved and reveal the receptor forming a dimer with two anions bound at the termini of the hydrogen bonded assembly.
\end{abstract}

Keywords

Anion receptors, amides, urea, crystallography

Amides and urea groups have been employed in a wide variety of anion receptor systems over recent years. ${ }^{1}$ We have been interested in the anion complexation properties of a variety of simple linear hydrogen bond donor molecules. ${ }^{2}$ In 2000 , 
Reinhoudt and co-workers reported the anion binding ability of cyclic and acyclic receptors containing two ortho-phenylenediamine based bis-urea units with the receptor showing selectivity for dihydrogen phosphate anions in DMSO solution. ${ }^{3}$ We have synthesised a variety of simple acyclic ortho-phenylenediamine systems e.g. $\mathbf{1}$ and demonstrated a general selectivity of these receptors for carboxylates in DMSO$d_{6} / 0.5 \%$ water solution. ${ }^{4-6}$ In this short paper we report the synthesis of two new bisurea compounds $\mathbf{2}$ and $\mathbf{3}$ (Schemes 1 and 2) that have appended amide groups. We wished to ascertain whether the extra hydrogen bond donor groups in these receptors would contribute to the stability of the oxo-anion complexes.

\section{Insert structure of 1 here}

\section{Experimental}

Compound 6: 1,1'-(1,2-Phenylene)bis(3-(2-aminophenyl)urea)

$10 \% \mathrm{Pd} / \mathrm{C}(0.04 \mathrm{~g}, 0.1 \mathrm{mmol})$ and hydrazine monohydrate $(1.4 \mathrm{~mL})$ was added to a stirring suspension of compound $5(1.33 \mathrm{~g}, 3.0 \mathrm{mmol})$ in $\mathrm{EtOH}(200 \mathrm{~mL})$ and the reaction was heated to reflux for 16 hours under a nitrogen atmosphere. The reaction was then removed from reflux and allowed to cool to room temperature and the resulting white precipitate and $\mathrm{Pd} / \mathrm{C}$ removed via filtration. The product was redissolved in a small volume of DMF ( $5 \mathrm{~mL}$ ) and filtered to remove Pd/C. Removal of DMF under reduced pressure yielded a white precipitate in a green oil. The product was removed via filtration and washed with $\mathrm{H}_{2} \mathrm{O}(3 \times 10 \mathrm{~mL})$ followed by 
methanol $(3 \times 10 \mathrm{~mL})$ before drying under high vacuum affording the product as a white powder. Mass of product $=0.88 \mathrm{~g}$. Yield $=78 \% .{ }^{1} \mathrm{H}$ NMR $-300 \mathrm{MHz}$ $\left(\mathrm{DMSO}-d_{6}\right) \delta(\mathrm{ppm}): 8.37(\mathrm{~s}, 2 \mathrm{H}$, urea NH$), 8.29(\mathrm{~s}, 2 \mathrm{H}$, urea $\mathrm{NH}), 7.64(\mathrm{dd}, 2 \mathrm{H}, \mathrm{J}=$ $5.6 \& 3.4 \mathrm{~Hz}, \operatorname{ArH}), 7.36(\mathrm{~d}, 2 \mathrm{H}, \mathrm{J}=7.9 \mathrm{~Hz}, \operatorname{ArH}), 7.02(\mathrm{dd}, 2 \mathrm{H}, \mathrm{J}=5.6 \& 3.8 \mathrm{~Hz}$ ArH), $6.82(\mathrm{t}, 2 \mathrm{H}, \mathrm{J}=7.1 \mathrm{~Hz}, \operatorname{ArH}), 6.71(\mathrm{~d}, 2 \mathrm{H}, \mathrm{J}=7.5 \mathrm{~Hz}, \operatorname{ArH}), 6.55(\mathrm{t}, 2 \mathrm{H}, \mathrm{J}=7.5$ $\mathrm{Hz}, \mathrm{ArH}), 4.90$ (bs, 4H, NH$\left.{ }_{2}\right) .{ }^{13} \mathrm{C} \mathrm{NMR}-75 \mathrm{MHz}$ (DMSO- $\left.d_{6}\right) \delta(\mathrm{ppm}): 153.7(\mathrm{CO})$, $140.8(\mathrm{C}), 131.1(\mathrm{CH}), 124.5(\mathrm{CH}), 124.2(\mathrm{C}), 123.7(\mathrm{C}), 123.2(\mathrm{CH}), 116.4(\mathrm{CH})$, $115.5(\mathrm{CH})$. IR $\left(\mathrm{cm}^{-1}\right): 3353,3295,1728,1664,1579,1492,1431,1338,1262,1184$, 1141. LRMS (ES+): $376.9[\mathrm{M}+\mathrm{H}]^{+}, 398.9[\mathrm{M}+\mathrm{Na}]^{+}, 439.9[\mathrm{M}+\mathrm{Na}+\mathrm{MeCN}]^{+}, 753.1$ $[2 \mathrm{M}+\mathrm{H}]^{+}, 775.1[2 \mathrm{M}+\mathrm{Na}]^{+}, 1129.2[3 \mathrm{M}+\mathrm{Na}]^{+}, 1152.3[3 \mathrm{M}+\mathrm{Na}]^{+} . \quad \mathrm{HRMS}(\mathrm{ES}+)$ : Calculated Mass $=377.1721$. Observed Mass $=377.1721 . \Delta=0.06 \mathrm{ppm}$.

\section{Compound \\ 3: \\ Phenylenebis(azanediyl))bis(oxomethylene)bis(azanediyl)bis(2,1- phenylene))dibenzamide}

$N, N^{\prime}-\left(2,2^{\prime}-(1,2-\right.$

Benzoyl chloride $(0.74 \mathrm{~mL}, 6.4 \mathrm{mmol})$ in DMF (dry) was added dropwise over a 15 minute period and to a stirred solution of compound 6 (1.20 g, $3.2 \mathrm{mmol})$, triethylamine $(0.76 \mathrm{~mL}, 7.1 \mathrm{mmol})$ and DMAP (0.01g, cat.) in anhydrous DMF (50 $\mathrm{mL}$ ) under a nitrogen atmosphere. The reaction was stirred at room temperature for 18 hours before being filtered to remove precipitated triethylamine hydrochloride. The remaining DMF was removed in vacuo to give an oily brown residue that was redissolved in dichloromethane $(50 \mathrm{~mL})$. The solution was washed with water $(3 \times 50$ $\mathrm{mL}$ ) and the organic phase retained, dried over anhydrous $\mathrm{MgSO}_{4}$ and filtered before the removal of solvent in vacuo. The resulting brown solid was washed with ethyl 
acetate $(10 \mathrm{~mL})$, and then hot ethyl acetate $(3 \times 10 \mathrm{~mL})$, giving a white solid, dried under high vacuum. Mass of product $=0.55 \mathrm{~g}$. Yield $=29 \% .{ }^{1} \mathrm{H}$ NMR $300 \mathrm{MHz}$ $\left(\mathrm{DMSO}-d_{6}\right) \delta(\mathrm{ppm}): 10.02(\mathrm{~s}, 2 \mathrm{H}, \mathrm{NH}), 8.58(\mathrm{~s}, 2 \mathrm{H}, \mathrm{NH}), 8.44(\mathrm{~s}, 2 \mathrm{H}, \mathrm{NH}), 8.00$ $(\operatorname{app~d}, 4 \mathrm{H}, \mathrm{J}=7.0 \mathrm{~Hz}, \operatorname{ArH}), 7.77(\mathrm{dd}, 2 \mathrm{H}, \mathrm{J}=8.0 \& 1.0 \mathrm{~Hz}, \operatorname{ArH}), 7.50(\mathrm{~m}, 10 \mathrm{H}$, ArH), $7.20(\mathrm{td}, 2 \mathrm{H}, \mathrm{J}=7.9 \& 1.1 \mathrm{~Hz}, \mathrm{ArH}), 7.04(\mathrm{~m}, 4 \mathrm{H}, \mathrm{ArH}) .{ }^{13} \mathrm{C} \mathrm{NMR}-75 \mathrm{MHz}$ $\left(\mathrm{DMSO}-d_{6}\right) \delta(\mathrm{ppm}): 165.6(\mathrm{CO}), 153.8(\mathrm{CO}), 134.2(\mathrm{C}), 133.9(\mathrm{C}), 131.1(\mathrm{CH})$, $128.6(\mathrm{C}), 128.4(\mathrm{CH}), 127.7(\mathrm{CH}), 126.9(\mathrm{CH}), 126.1(\mathrm{CH}), 124.0(\mathrm{CH}), 123.0(\mathrm{CH})$, $122.5(\mathrm{CH}) . \mathrm{IR}\left(\mathrm{cm}^{-1}\right): 3288,3057,1654,1596,1507,1439,1309,1206,757$. LRMS (ES): $619.3[\mathrm{M}+\mathrm{Cl}]^{-}, 697.2[\mathrm{M}+\mathrm{TFA}-\mathrm{H}]^{-}, 1203.6[2 \mathrm{M}+\mathrm{Cl}]^{-}, 1281.1[2 \mathrm{M}+\mathrm{TFA}-\mathrm{H}]^{-}$. Microanalysis for $\mathrm{C}_{34} \mathrm{H}_{28} \mathrm{~N}_{6} \mathrm{O}_{4}$. Expected (\%) $\mathrm{C}=69.85 \mathrm{H}=4.83 \mathrm{~N}=14.37$. Found (\%) $\mathrm{C}=69.54 \mathrm{H}=4.81 \mathrm{~N}=14.38$.

Compound 4: diethyl 3,3'-(1,2phenylenebis(azanediyl))bis(oxomethylene)bis(azanediyl)dibenzoate 3-Ethylisocyanatobenzoate $(2.16 \mathrm{~mL}, 13.1 \mathrm{mmol})$ was added dropwise to a stirring solution of ortho-phenylenediamine $(0.71 \mathrm{~g}, 6.5 \mathrm{mmol})$ in dry dichloromethane (150 $\mathrm{mL}$ ). Within 5 minutes of addition the reaction mixture formmed a viscous gel. At this point $\mathrm{MeOH}(5 \mathrm{~mL})$ was then added to dissolve the gel. The reaction was left at room temperature for 16 hours, after which solvent was removed from reaction via rotary evaporation. The product was recrystalized from boiling $\mathrm{MeOH}$ before washing with $\mathrm{Et}_{2} \mathrm{O}(3 \times 20 \mathrm{~mL})$ and drying under high vacuum. The product was isolated as a white solid. Mass of product $=2.74 \mathrm{~g}$. Yield $=86 \%$. ${ }^{1} \mathrm{H}$ NMR 300 MHz (DMSO-d $d_{6} \delta(\mathrm{ppm}): 9.35$ (s, 2H, NH), 8.15 (s, 2H, ArH), 8.07 (s, 2H, NH), $7.70(\mathrm{~m}, 2 \mathrm{H}, \mathrm{ArH}), 7.60(\mathrm{~m}, 2 \mathrm{H}, \mathrm{ArH}), 7.55(\mathrm{~m}, 2 \mathrm{H}, \operatorname{ArH}), 7.41(\mathrm{t}, 2 \mathrm{H}, \mathrm{J}=7.9 \mathrm{~Hz}$, ArH), $7.11(\mathrm{dd}, 2 \mathrm{H}, \mathrm{J}=6.0 \& 3.8 \mathrm{~Hz}, \operatorname{ArH}), 4.30\left(\mathrm{q}, 4 \mathrm{H}, \mathrm{J}=7.1 \mathrm{~Hz}, \mathrm{CH}_{2}\right), 1.31(\mathrm{t}$, 
$\left.6 \mathrm{H}, \mathrm{J}=7.1 \mathrm{~Hz}, \mathrm{CH}_{3}\right) .{ }^{13} \mathrm{C} \mathrm{NMR}-100 \mathrm{MHz}\left(\mathrm{DMSO}-d_{6}\right) \delta(\mathrm{ppm}): 166.2(\mathrm{CO}), 153.7$

(CO), $140.7(\mathrm{C}), 131.8(\mathrm{C}), 130.9(\mathrm{C}), 129.6(\mathrm{CH}), 124.7(\mathrm{CH}), 124.7(\mathrm{CH}), 123.1$

$(\mathrm{CH}), 122.9(\mathrm{CH}), 119.0(\mathrm{CH}), 61.2\left(\mathrm{CH}_{2}\right), 14.6\left(\mathrm{CH}_{3}\right) . \mathrm{IR}\left(\mathrm{cm}^{-1}\right):$ 3351, 3245, 2980.

1724, 1652, 1559, 1458, 1280, 1251, 1217, 1103, 752. LRMS (ES): $491.3[\mathrm{M}+\mathrm{H}]^{+}$,

$513.3[\mathrm{M}+\mathrm{Na}]^{+}, 100.3[2 \mathrm{M}+\mathrm{Na}]^{+}$. Microanalysis for $\mathrm{C}_{26} \mathrm{H}_{26} \mathrm{~N}_{4} \mathrm{O}_{6}$. Expected $(\%) \mathrm{C}=$ $63.66 \mathrm{H}=5.34 \mathrm{~N}=11.42$. Found $(\%) \mathrm{C}=63.46 \mathrm{H}=5.34 \mathrm{~N}=11.34$.

\section{Compound}

2:

$3,3^{\prime}-(1,2-$

\section{Phenylenebis(azanediyl))bis(oxomethylene)bis(azanediyl)bis( $N$ - phenylbenzamide)}

Aniline $(0.40 \mathrm{~mL}, 4.1 \mathrm{mmol})$ was dissolved in dry dichloromethane $(40 \mathrm{~mL})$ and $2 \mathrm{M}$ trimethylaluminium in hexanes $(2.03 \mathrm{~mL}, 4.06 \mathrm{mmol})$ added dropwise under a nitrogen atmosphere. Reagents were left stirring under nitrogen for 30 minutes at which time compound $4(1.00 \mathrm{~g}, 2.03 \mathrm{mmol})$ wass added to the reaction mixture. The reaction was heated at reflux for 5 days under a nitrogen atmosphere. The reaction was allowed to cool and $2 \mathrm{M}$ aqueous $\mathrm{HCl}$ solution was then added until reaction ceased bubbling resulting in the precipitation of the product. A further $20 \mathrm{~mL}$ of water was added and the mixture stirred for a further 15 minutes. The organic phase and precipitate were washed with water $(3 \times 50 \mathrm{~mL})$. The organic phase containing the precipitate was then filtered and the white precipitate washed with $\mathrm{Et}_{2} \mathrm{O}(3 \times 20$ $\mathrm{mL}$ ) before drying under high vacuum. Mass of product $=0.94 \mathrm{~g}$. Yield $=94 \% .{ }^{1} \mathrm{H}$ NMR 300 MHz (DMSO-d $\left.d_{6}\right) \delta(\mathrm{ppm}): 10.22$ (s, 2H, NH), 9.33 (s, 2H, NH), 8.15 (s, 2H, NH), $8.00(\mathrm{~s}, 2 \mathrm{H}, \mathrm{ArH}), 7.76(\mathrm{~m}, 6 \mathrm{H}, \mathrm{ArH}), 7.63(\mathrm{~m}, 2 \mathrm{H}, \mathrm{ArH}), 7.56(\mathrm{~m}, 2 \mathrm{H}$, ArH), $7.43(\mathrm{t}, 2 \mathrm{H}, \mathrm{J}=7.7 \mathrm{~Hz}, \operatorname{ArH}), 7.35(\mathrm{t}, 4 \mathrm{H}, \mathrm{J}=7.7 \mathrm{~Hz}, \operatorname{ArH}), 7.11(\mathrm{~m}, 4 \mathrm{H}, \operatorname{ArH})$. ${ }^{13} \mathrm{C}$ NMR - 75 MHz (DMSO- $\left.d_{6}\right) \delta(\mathrm{ppm}): 165.6(\mathrm{CO}), 153.2(\mathrm{CO}), 140.1(\mathrm{C}), 139.2$ 
(C), $135.8(\mathrm{C}), 131.3(\mathrm{C}), 128.8(\mathrm{CH}), 128.6(\mathrm{CH}), 124.2(\mathrm{CH}), 124.1(\mathrm{CH}), 123.6$

$(\mathrm{CH}), 121.1(\mathrm{CH}), 120.8(\mathrm{CH}), 120.3(\mathrm{CH}), 117.6(\mathrm{CH}) . \mathrm{IR}\left(\mathrm{cm}^{-1}\right)$ : 3351, 3250, 2980, 1724, 1648, 1555, 1462, 1280, 1217, 1103, 1026, 752. LRMS (ES): $619.1[\mathrm{M}+\mathrm{Cl}]^{-}$, $696.9[\mathrm{M}+\mathrm{TFA}-\mathrm{H}]^{-}, 1203.4[2 \mathrm{M}+\mathrm{Cl}]^{-}, 1281.3[2 \mathrm{M}+\mathrm{TFA}-\mathrm{H}]^{-}, 1787.9[3 \mathrm{M}+\mathrm{Cl}]^{-}$. Microanalysis for $\mathrm{C}_{34} \mathrm{H}_{28} \mathrm{~N}_{6} \mathrm{O}_{4}+0.4 \mathrm{CH}_{2} \mathrm{Cl}_{2}$. Expected $(\%) \mathrm{C}=66.79 \mathrm{H}=4.69 \mathrm{~N}=$ 13.59. Found (\%) $\mathrm{C}=66.60 \mathrm{H}=4.90 \mathrm{~N}=13.58$.

X-ray crystallography

Cell dimensions and intensity data were recorded at 120K, using a Bruker Nonius KappaCCD area detector diffractometer mounted at the window of a rotating Mo anode $(\lambda(\mathrm{Mo}-\mathrm{K} \alpha)=0.71073 \AA)$. The crystal-to-detector distance was $30 \mathrm{~mm}$ and $\phi$ and $\Omega$ scans were carried out to fill the asymmetric unit. Data collection and processing were carried out using the programs COLLECT $^{8}$, and DENZO ${ }^{9}$ and an empirical absorption correction was applied using SADABS. ${ }^{10}$

The structures were solved via direct methods ${ }^{11}$ and refined by full matrix least squares on $\mathrm{F}^{2}$. Non-hydrogen atoms were refined anisotropically and hydrogen atoms were treated using a riding model. The number of observed reflections was less than $50 \%$ and this is a contributing factor to the slightly high R-factors.

Crystal data for compound 3: $\mathrm{C}_{34} \mathrm{H}_{28} \mathrm{~N}_{6} \mathrm{O}_{4}, \mathrm{Mr}=584.62, \mathrm{~T}=120(2) \mathrm{K}$, monoclinic, space group $P 2{ }_{1} / c, a=9.2368(5), b=27.4133(16), c=11.6115(7) \AA, \beta=96.593(2)^{\circ}$, $V=2920.7(3) \AA^{3}, \rho_{\text {calc }}=1.330 \mathrm{~g} \mathrm{~cm}^{-3}, \mu=0.090 \mathrm{~mm}^{-1}, \mathrm{Z}=4$, reflections collected: 26187, independent reflections: $6645\left(R_{\mathrm{int}}=0.0420\right)$, final $R$ indices $[I>2 \sigma I]: R 1=$ 
$0.0415, w R 2=0.0980, R$ indices (all data): $R 1=0.0635 . w R 2=0.1085 . \mathrm{CCDC}$ 607431.

Compound 3 - tetrabutylammonium acetate complex: $\mathrm{C}_{52} \mathrm{H}_{67} \mathrm{~N}_{7} \mathrm{O}_{6}, \mathrm{Mr}=886.13, \mathrm{~T}=$ 120(2) K, triclinic, space group $P-1, a=13.3008(4), b=14.9187(4), c=25.3629(7)$ $\AA, \alpha=97.297(2), \beta=96.686(1), \gamma=97.262(2)^{\circ}, V=4906.9(2) \AA^{3}, \rho_{\text {calc }}=1.199 \mathrm{~g} \mathrm{~cm}$ ${ }^{-3}, \mu=0.079 \mathrm{~mm}^{-1}, \mathrm{Z}=4$, reflections collected: 88632 , independent reflections: $21661\left(R_{\text {int }}=0.1139\right)$, final $R$ indices $[I>2 \sigma I]: R 1=0.0914, w R 2=0.1778, R$ indices (all data): $R 1=0.1995 . w R 2=0.2171$. CCDC 607429

Compound 3 - tetrabutylammonium benzoate complex: $\mathrm{C}_{57} \mathrm{H}_{69} \mathrm{~N}_{7} \mathrm{O}_{6}, \mathrm{Mr}=948.19, \mathrm{~T}$ $=120(2) \mathrm{K}$, triclinic, space group $P-1, a=9.2831(3), b=10.9968(6), c=24.9522(13)$ $\AA, \alpha=91.299(2), \beta=92.310(3), \gamma=97.775(3)^{\circ}, V=2520.7(2) \AA^{3}, \rho_{\text {calc }}=1.249 \mathrm{~g} \mathrm{~cm}^{-}$ ${ }^{3}, \mu=0.082 \mathrm{~mm}^{-1}, \mathrm{Z}=2$, reflections collected: 40028, independent reflections: 11395 $\left(R_{\text {int }}=0.1568\right)$, final $R$ indices $[I>2 \sigma I]: R 1=0.0809, w R 2=0.1712, R$ indices (all data): $R 1=0.2068 . w R 2=0.2162$. CCDC 607430

\section{Results and Discussion}

Compound 4 was synthesised by reaction of 3-ethylisocyanatobenzoate with orthophenylenediamine in dry dichloromethane. Reaction of this compound with the aluminium amide $^{7}$ species resulting from the reaction of aniline and trimethylaluminium afforded compound 2. (Scheme 1).

\section{Scheme 1 (i) Aniline, $\mathrm{AlMe}_{3} / \mathrm{CH}_{2} \mathrm{Cl}_{2} /$ hexane}

Compound 5 was synthesised according to literature methods. ${ }^{5}$ This compound was reduced by addition of $\mathrm{Pd} / \mathrm{C}$ and hydrazine monohydrate in ethanol affording compound 6. This was coupled to benzoyl chloride to afford the bis-amide $\mathbf{3}$. 
Scheme 2 (i) Pd/C, hydrazine (ii) benzoyl chloride, Et 3 N, DMAP (cat), DMF.

Crystals of compound $\mathbf{3}$ were grown from a DMSO solution of the receptor. The structure of the receptor was elucidated by single crystal X-ray diffraction and is shown in Figure 1. The molecule forms chains along the a-axis via amide $\mathrm{NH}^{\cdots}$ amide $\mathrm{O}$ and urea $\mathrm{NH}^{\cdots}$ urea $\mathrm{OC}$ hydrogen bonds (Figure 2).

Figure 1 The X-ray crystal structure of compound $\mathbf{3}$.

Figure 2 The hydrogen-bonded chain in crystals of compound $\mathbf{3}$ extending along the $a$ axis in the solid-state

${ }^{1} \mathrm{H}$ NMR titrations were performed with compounds $\mathbf{2}$ and $\mathbf{3}$ and a variety of putative anionic guests (as tetrabutylammonium salts) in DMSO- $d_{6} / 0.5 \%$ water at $298 \mathrm{~K}$. The NMR titration curves for compound 2 are shown in Figure 3. Stability constants were determined using the EQNMR computer program (Table 1). ${ }^{12}$ Compound 2 was found to have very similar affinities for anions as the parent compound $\mathbf{1}$ with the exception that dihydrogen phosphate is bound with a stability constant approximately three times more strongly by compound $\mathbf{2}$ than compound $\mathbf{1}$. This may be due to the participation of the terminal amide groups in dihydrogen phosphate complexation but not in benzoate complexation. Proposed structures for these complexes are shown in Figure 4. 
Figure $3{ }^{1} \mathrm{H}$ NMR titration curves of compound 2 (central urea $\mathrm{NH}$ ) upon addition of anions as tetrabutylammonium salts in DMSO- $\mathrm{d}_{6} / 0.5 \%$ water solution. 


\begin{tabular}{|c|c|c|c|}
\hline & \multicolumn{3}{|c|}{ Stability constants $\mathrm{K}\left(\mathrm{M}^{-1}\right) \beta\left(\mathrm{M}^{-2}\right)$} \\
\hline Anion & $\mathbf{1}$ & $\mathbf{2}^{\mathbf{a}}$ & $\mathbf{3}$ \\
\hline $\mathrm{Cl}^{-}$ & 43 & 54 & 17 \\
\hline $\mathrm{HSO}_{4}^{-}$ & 10 & 12 & - \\
\hline $\mathrm{H}_{2} \mathrm{PO}_{4}^{-}$ & 732 & 2290 & $\mathrm{~K}_{1}=7780$ \\
& & & $\mathrm{~K}_{2}=24$ \\
& & & $\beta_{2}=185000$ \\
\hline $\mathrm{CH}_{3} \mathrm{CO}_{2}^{-}$ & 3210 & 3200 & $\mathrm{~K}_{1}=6010$ \\
& & & $\mathrm{~K}_{2}=<10$ \\
& & & $\beta_{2}=55230$ \\
\hline $\mathrm{C}_{6} \mathrm{H}_{5} \mathrm{CO}_{2}^{-}$ & 1330 & 974 & $\mathrm{~K}_{1}=10110$ \\
& & & $\mathrm{~K}_{2}=<10$ \\
& & & $\beta_{2}=16554$ \\
\hline
\end{tabular}

a Non-random residual errors in the fitting of the data for oxo-anions with compound 2 is evidence that leads us to suggest that other stoichiometries may be present in solution. However it was found that the most satisfactory fit that could be obtained was to a 1:1 binding model.

Table 1 Stability constants of compounds $\mathbf{1 , 2}$ and $\mathbf{3}$ with anionic guests added as tetrabutylammonium salts in DMSO- $\mathrm{d}_{6} / 0.5 \%$ water solution at $298 \mathrm{~K}$. Errors in fitting estimated $<15 \%$. 
Figure 4 Proposed structures of the complexes of a) benzoate and b) dihydrogen phosphate with compound 2.

Compound $\mathbf{3}$ exhibits a higher affinity for oxo-anions than compound $\mathbf{2}$ and also a propensity to form 1:2 receptor:anion complexes albeit with low $\mathrm{K}_{2}$ values. Unfortunately for solubility reasons studies were limited to DMSO- $\mathrm{d}_{6} / 0.5 \%$ water solutions and so low variable temperature NMR experiments could not be performed to help elucidate the structure of the complex in solution. Figure 5 shows possible structures for solution state complexes with benzoate. The high $\mathrm{K}_{1}$ values lead us to suggest that complex a) predominates in solution at lower anion concentrations.

Figure 5 Possible binding modes of benzoate to compound 3 in a) and b) 1:1 stoichiometry and c) and d) 1:2 stoichiometry.

Crystals of the acetate and benzoate complexes of compound $\mathbf{3}$ were obtained by slow evaporation of an acetonitrile solution of the receptor in the presence of the excess tetrabutylammonium anion salt. The structures were elucidated by X-ray crystallography (Figures 6 and 7) and reveal that both complexes adopt a similar arrangement in the solid-state which can be regarded as a dimer formed by complexes 
of type b) in Figure 5. The anions are bound at the ends of the dimer with the NH and OC group which are not involved in intramolecular hydrogen bonding in Fiure $5 \mathrm{~b}$ forming a cyclic hydrogen bonding array with another receptor. Hydrogen bonding interactions in the two complexes are tabulated in Tables 2 (acetate) and 3 (benzoate).

Figure 6 The X-ray crystal structure of the tetrabutylammonium acetate complex of receptor 3 (counter cation and non-acidic hydrogen atoms omitted for clarity) showing one of the dimers present in the unit cell binding two acetate anions.

Figure 7 The X-ray crystal structure of the tetrabutylammonium benzoate complex of receptor 3 (counter cation and non-acidic hydrogen atoms omitted for clarity) the dimers present in the unit cell binding two benzoate anions.

Table 2. Hydrogen bonds lengths and angles in the acetate complex of compound $\mathbf{3}$. $\left[\AA\right.$ and $^{\circ}$ ]

\begin{tabular}{|c|c|c|c|c|}
\hline$D-\mathrm{H} \cdots A$ & $d(D-\mathrm{H})$ & $d(\mathrm{H} \cdots A)$ & $d(D \cdots A)$ & $\angle(D H A)$ \\
\hline N101-H101‥O102 & 0.88 & 1.92 & $2.683(3)$ & 143.7 \\
\hline N203-H203 …2203 & 0.88 & 2.01 & $2.738(4)$ & 139.8 \\
\hline N103-H103...O103 & 0.88 & 2.01 & $2.737(4)$ & 138.8 \\
\hline N104-H104...O502 & 0.88 & 2.05 & $2.780(3)$ & 139.8 \\
\hline N105-H105...O501 & 0.88 & 1.97 & $2.837(4)$ & 167.8 \\
\hline N106-H106”O501 & 0.88 & 2.13 & $2.954(4)$ & 156.5 \\
\hline N201-H201…O202 & 0.88 & 1.92 & $2.682(3)$ & 143.8 \\
\hline $\mathrm{N} 102-\mathrm{H} 102 \ldots \mathrm{O} 101^{\mathrm{i}}$ & 0.88 & 2.06 & $2.897(3)$ & 158.9 \\
\hline $\mathrm{N} 202-\mathrm{H} 202 \ldots \mathrm{O} 201^{\mathrm{ii}}$ & 0.88 & 2.10 & $2.924(4)$ & 155.0 \\
\hline $\mathrm{N} 204-\mathrm{H} 204 \ldots \mathrm{O} 602^{\mathrm{iii}}$ & 0.88 & 2.05 & $2.803(4)$ & 143.5 \\
\hline $\mathrm{N} 205-\mathrm{H} 205 \cdots \mathrm{O} 601^{\mathrm{iii}}$ & 0.88 & 1.89 & $2.750(3)$ & 165.1 \\
\hline N206-H206…0601 ${ }^{\mathrm{iii}}$ & 0.88 & 2.12 & $2.953(4)$ & 158.5 \\
\hline
\end{tabular}


Symmetry transformations used to generate equivalent atoms:
(i) $-\mathrm{x},-\mathrm{y}+1,-\mathrm{z}$
(ii) $-\mathrm{x}+1,-\mathrm{y}+2,-\mathrm{z}$
(iii) $\mathrm{x}, \mathrm{y}+1, \mathrm{z}$

Table 3. Hydrogen bonds lengths and angles in the benzoate complex of compound $\mathbf{3}$. [^ and $^{\circ}$ ]

\begin{tabular}{|c|c|c|c|c|}
\hline$D-\mathrm{H} \cdots A$ & $d(D-\mathrm{H})$ & $d(\mathrm{H} \cdots A)$ & $d(D \cdots A)$ & $\angle(D H A)$ \\
\hline $\mathrm{N} 1-\mathrm{H} 91 \ldots \mathrm{O} 2$ & 0.88 & 1.94 & $2.698(4)$ & 142.6 \\
\hline $\mathrm{N} 2-\mathrm{H} 92 \ldots \mathrm{O} 1^{\mathrm{i}}$ & 0.88 & 2.22 & $3.030(4)$ & 152.4 \\
\hline N3-H93 ... & 0.88 & 1.98 & $2.709(4)$ & 139.8 \\
\hline N4-H94...O6 & 0.88 & 1.99 & $2.761(4)$ & 145.4 \\
\hline N5-H95 ... O5 & 0.88 & 1.97 & $2.830(4)$ & 165.3 \\
\hline N6-H96 ...O5 & 0.88 & 2.18 & $3.016(4)$ & 159.1 \\
\hline
\end{tabular}

Symmetry transformations used to generate equivalent atoms:

(i) $-\mathrm{x},-\mathrm{y},-\mathrm{z}$

\section{Conclusion}

Extending the hydrogen bond donor array has in the case of compound $\mathbf{3}$ resulted in a receptor with an enhanced affinity for anionic guests. X-ray crystallography has shown that in the solid-state carboxylate complexes of compound $\mathbf{3}$ dimerize with each anion bound by two urea and one amide hydrogen bond. We are continuing to investigate the anion binding properties of simple linear amidoureas and macrocyclic systems. These results will be published shortly.

\section{Acknowledgements}

We would like thank the EPSRC for a DTA studentship (SJB) and for use of the crystallographic facilities at the University of Southampton.

\section{References}


1. Sessler, J.L.; Gale, P.A.; Cho, W.S. Anion Receptor Chemistry (Monographs in Supramolecular Chemistry) Ed. Stoddart, J.F.; Royal Society of Chemistry, Cambridge UK, 2006; Schmidtchen, F.P.; Berger, M. Chem. Rev. 1997, 97, 1609; Antonisse, M.M.G.; Reinhoudt, D.N. Chem. Commun. 1998, 443; Pascal Jr., R.A.; Spergel, J.; van Engen, D. Tetrahedron Lett. 1986, 27, 4099; Valiyaveetil, S.; Engbersen, J.F.J.; Verboom, W.; Reinhoudt, D.N. Angew. Chem. Int. Ed. Engl. 1993, 32, 900; Beer, P.D. Acc. Chem. Rec. 1998, 31, 71; Kavallieratos, K.; Bertao, C.M.; Crabtree, R.H. J. Org. Chem. 1999, 64, 1675; Bondy, C.R.; Gale, P.A.; Loeb, S.J. Chem. Commun. 2001, 729; Choi, K.; Hamilton, A.D. J. Am. Chem. Soc. 2001, 123, 2456; Hossain, Md.A.; Llinares, J.M.; Powell, D.; Bowman-James, K. Inorg. Chem. 2001, 40, 2936; Smith, P.J.; Reddington, M.V.; Wilcox, C.S. Tetrahedron Lett. 1992, 33, 6085; Hughes, M.P.; Smith, B.D. J. Org. Chem. 1997, 62, 4492; Pernía, G.J.; Kilburn, J.D.; Essex, J.W.; Mortishire-Smith, R.J.; Rowley, M. J. Am. Chem. Soc. 1996, 118, 10220.

2. Gale, P.A. Acc. Chem. Res. in press; Gale, P.A. Chem. Commun. 2005, 3761.

3. Snellink-Ruël, B.H.M.; Antonisse, M.M.G.; Engbersen, J.F.J.; Timmerman P.; Reinhoudt, D.N. Eur. J. Org. Chem. 2000, 165.

4. Brooks, S.J.; Gale, P.A.; Light, M.E.; Chem. Commun. 2005, 4696.

5. Brooks, S.J.; Edwards, P.R.; Gale, P.A.; Light, M.E. New. J. Chem. 2006, 30, 65.

6. Brooks, S.J.; Gale, P.A.; Light, M.E.; CrystEngComm 2005, 7, 586.

7. Basha, A.; Lipton, M.; Weinreb, S. M. Tetrahedron Lett. 1977, 48, 4171.

8. COLLECT data collection software, Nonius B.V., 1998. 
9. Otwinowski, Z.; Minor, W. Methods in Enzymology, Volume 276:

Macromolecular Crystallography, Part A, Eds., Carter Jr., C.W.; Sweet, R.M. Academic Press. 1997, pp.307.

10. Sheldrick, G. M. SADABS - Bruker Nonius area detector scaling and absorption correction - V2.10.

11. SHELX97: Programs for Crystal Structure Analysis (Release 97-2). Sheldrick, G.M. Institüt für Anorganische Chemie der Universität, Tammanstrasse 4, D3400 Göttingen, Germany, 1998.

12. Hynes, M.J. J. Chem. Soc. Dalton Trans., 1993, 311. 


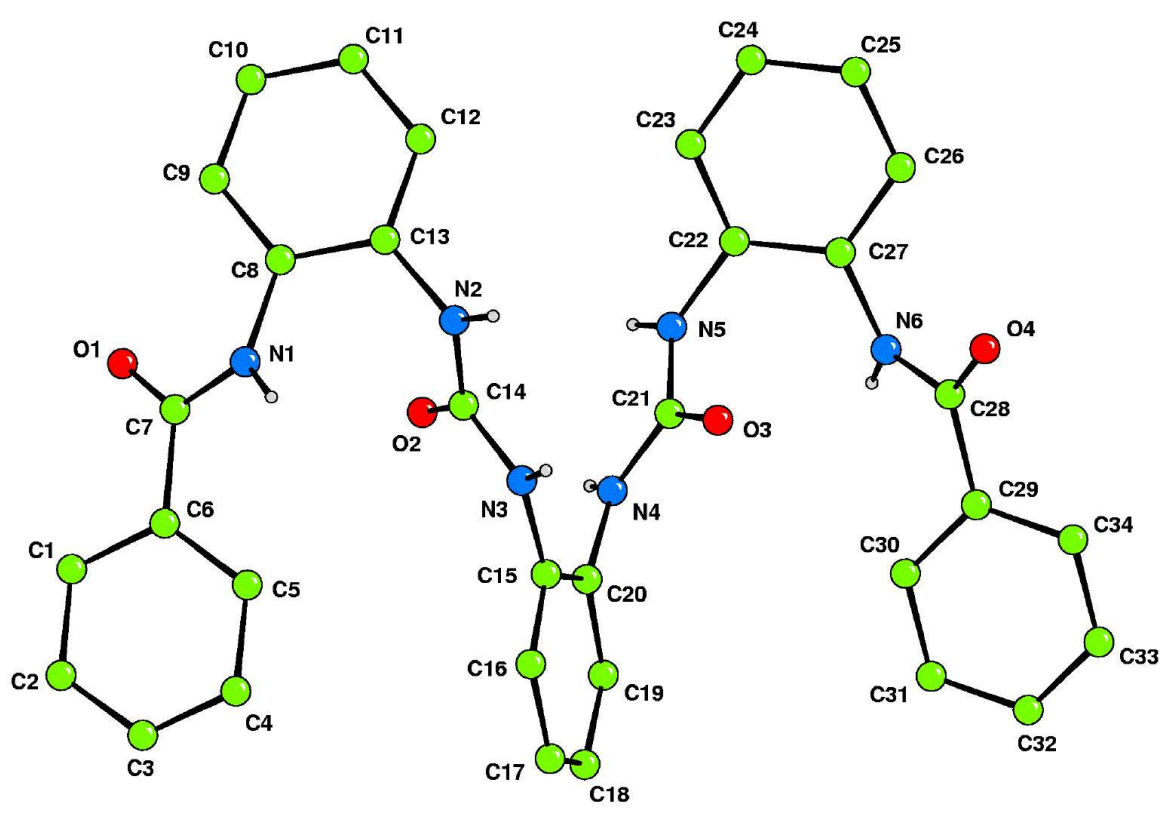

Figure 1 The X-ray crystal structure of compound 3 . $146 \times 101 \mathrm{~mm}(300 \times 300$ DPI $)$ 
1

2

3

4

5

6

7

8

10

11

12

13

14

15

16

17

18

19

20

21

22

23

24

25

26

27

28

29

30

31

32

33

34

35

36

37

38

39

40

41

42

43

44

45

46

47

48

49

50

51

52

53

54

55

56

57

58

59

60

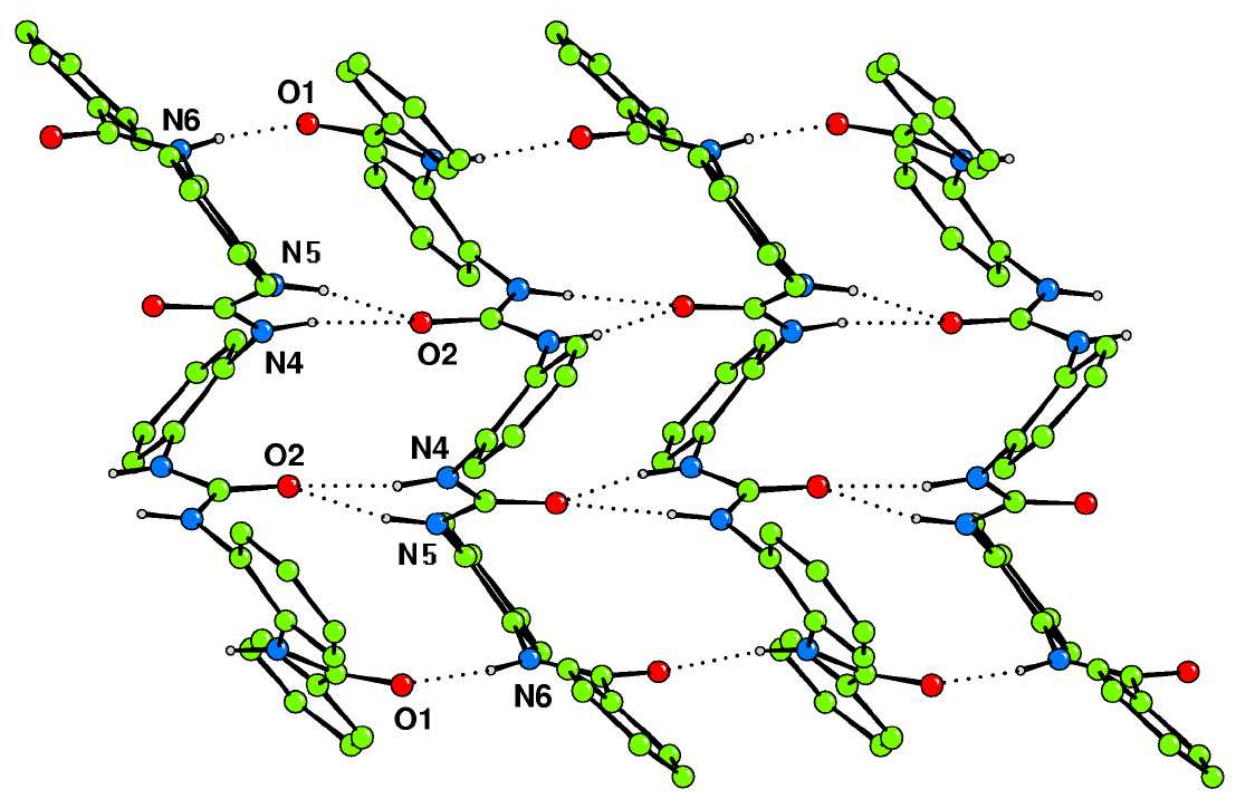

Figure 2 The hydrogen-bonded chain in crystals of compound 3 extending along the a axis in the solid-state

$98 \times 60 \mathrm{~mm}(300 \times 300 \mathrm{DPI})$ 


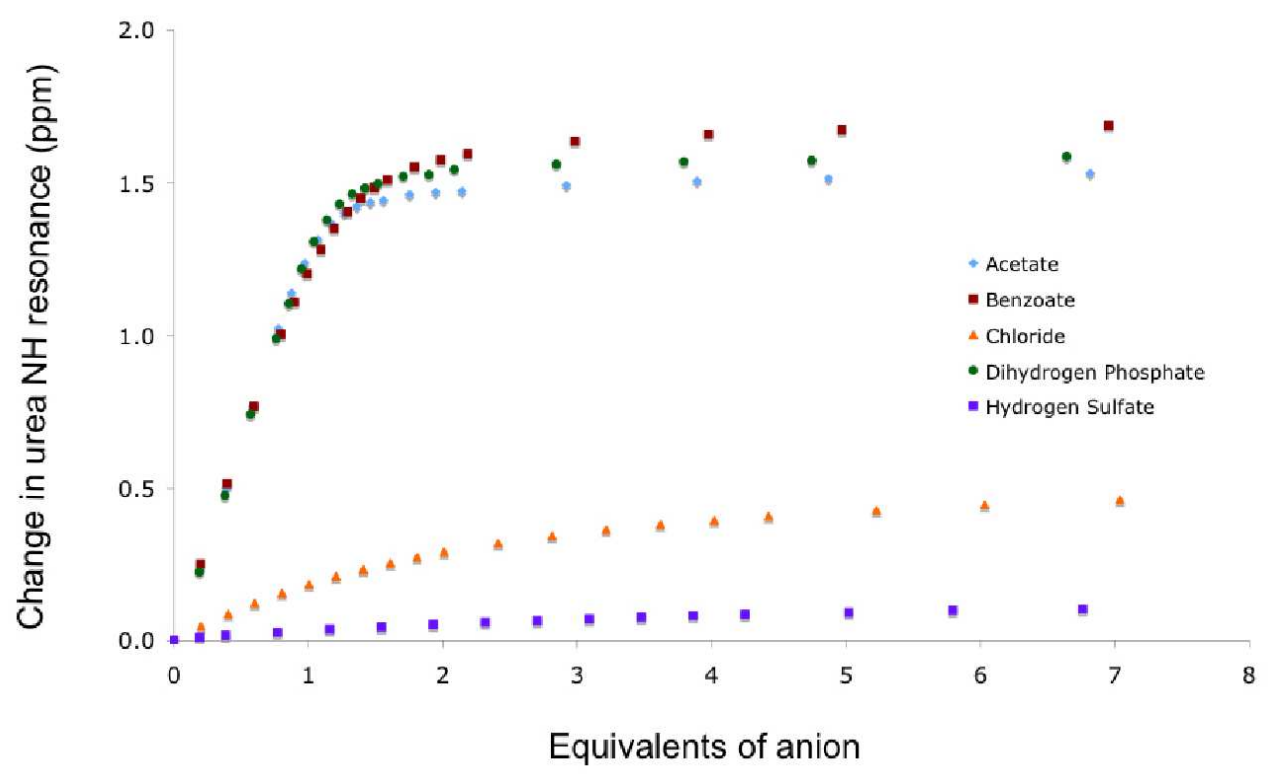

Figure $31 \mathrm{H}$ NMR titration curves of compound 2 (central urea $\mathrm{NH}$ ) upon addition of anions as tetrabutylammonium salts in DMSO-d6/0.5\% water solution. $111 \times 68 \mathrm{~mm}(300 \times 300 \mathrm{DPI})$ 


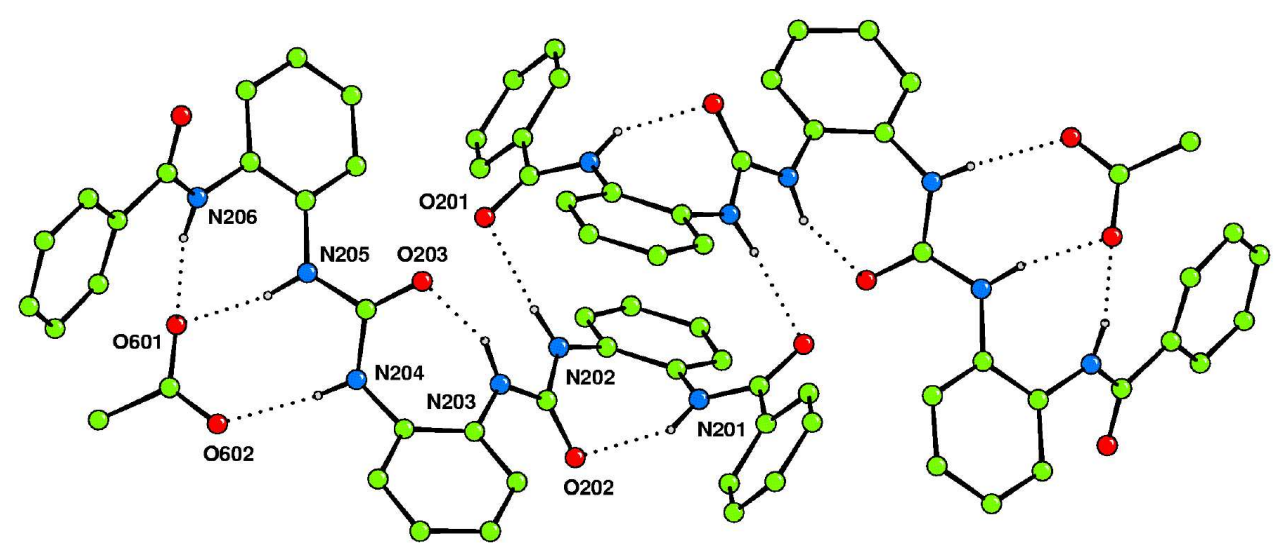

Figure 6 The X-ray crystal structure of the tetrabutylammonium acetate complex of receptor 3 (counter cation and non-acidic hydrogen atoms omitted for clarity) showing one of the dimers present in the unit cell binding two acetate anions. $156 \times 67 \mathrm{~mm}(300 \times 300 \mathrm{DPI})$ 


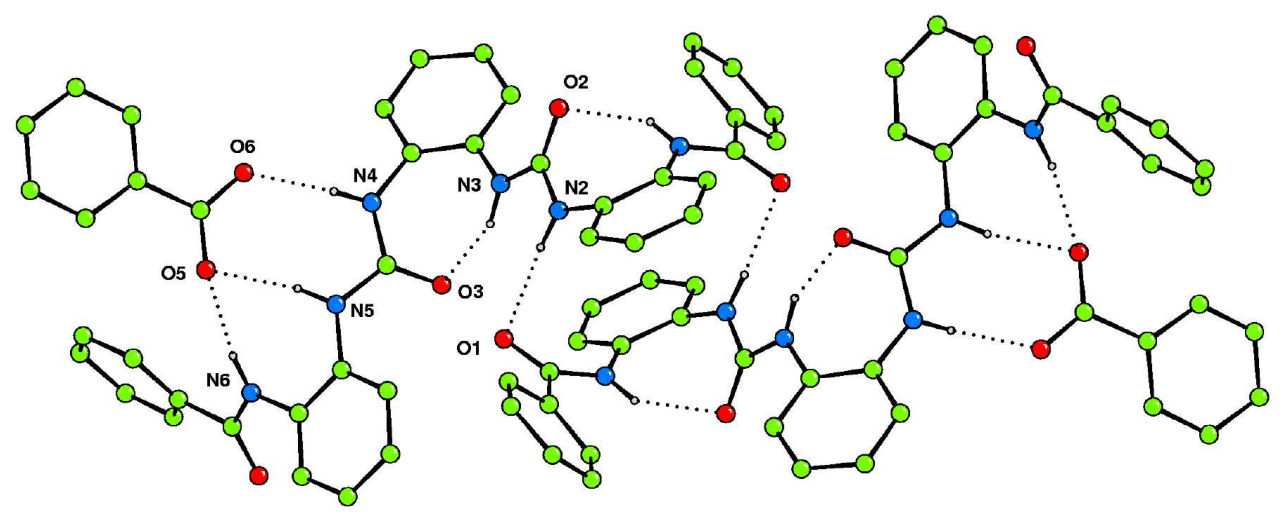

Figure 7 The X-ray crystal structure of the tetrabutylammonium benzoate complex of receptor 3 (counter cation and non-acidic hydrogen atoms omitted for clarity) the dimers present in the unit cell binding two benzoate anions. $156 \times 61 \mathrm{~mm}(300 \times 300 \mathrm{DPI})$ 
Extending the hydrogen-bonding array in ortho-phenylenediamine based bis-ureas

Simon J. Brooks, Philip A. Gale*, and Mark E. Light

School of Chemistry, University of Southampton, Southampton, SO17 1BJ, UK.

Supplementary information

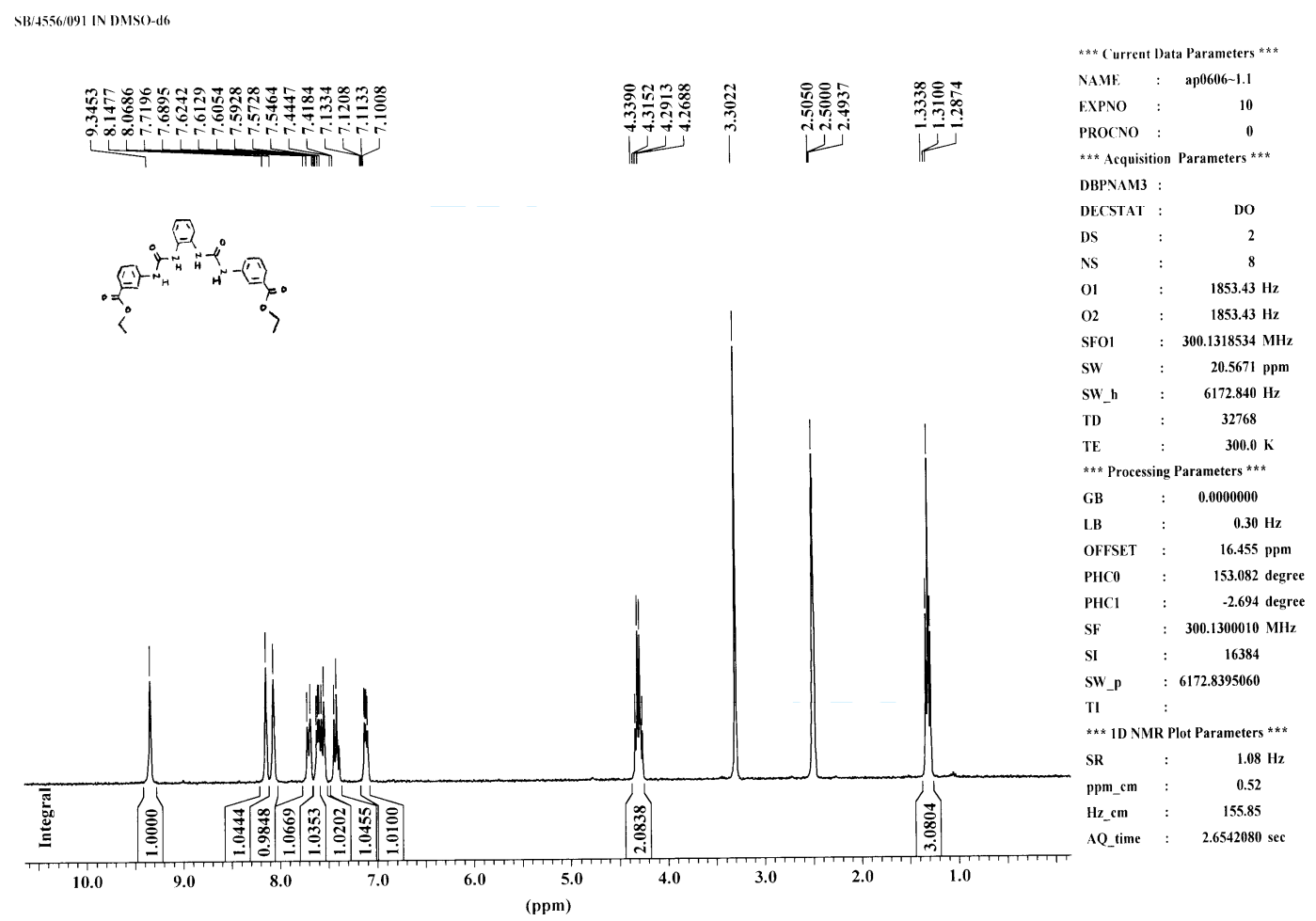

Figure $\mathrm{S} 1{ }^{1} \mathrm{H}$ NMR of compound 4 in DMSO- $\mathrm{d}_{6}$ 


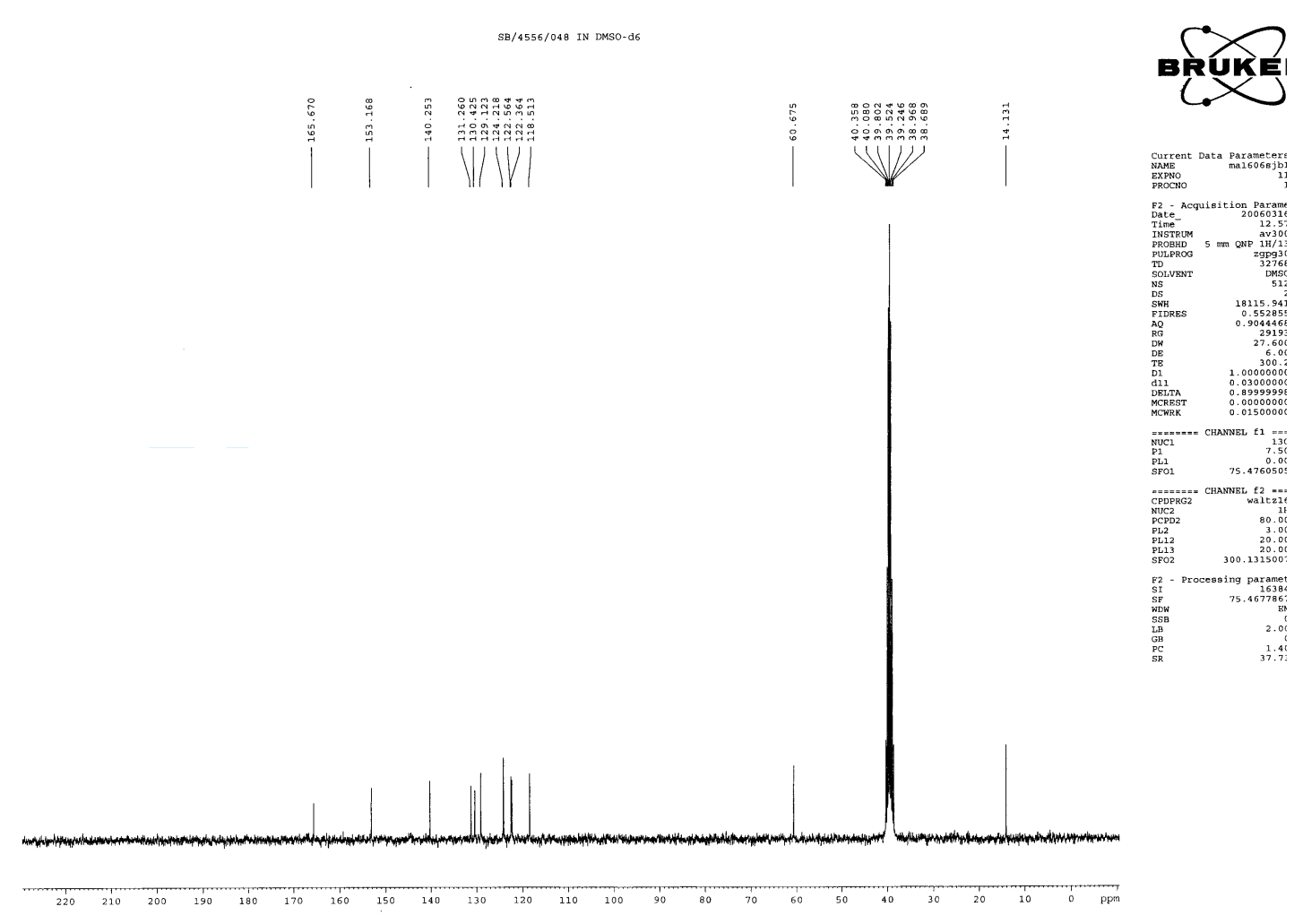

Figure $\mathrm{S} 2{ }^{13} \mathrm{C}$ NMR of compound 4 in DMSO- $\mathrm{d}_{6}$

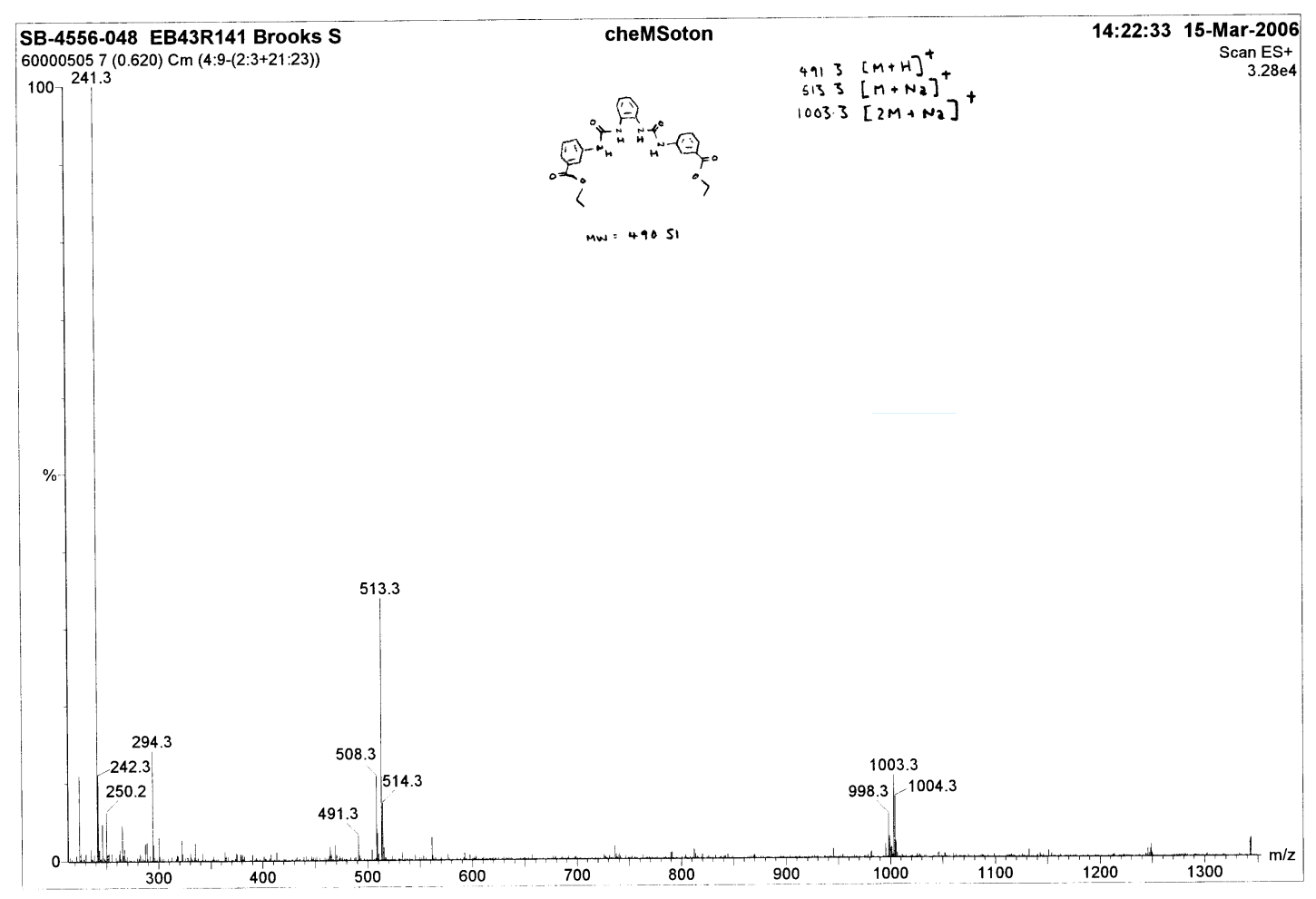

Figure S3 ES+ MS of compound 4 


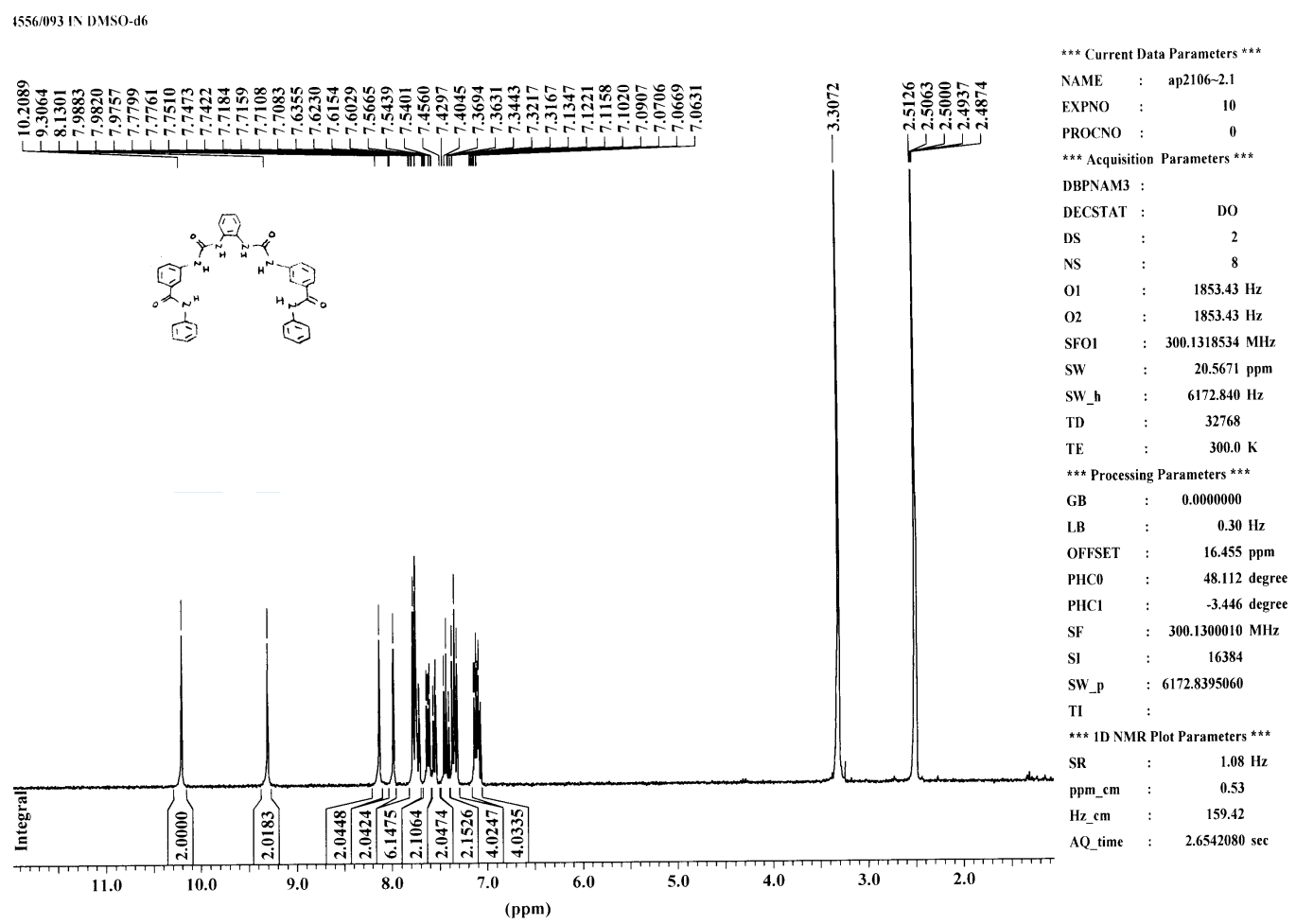

Figure S4 ${ }^{1} \mathrm{H}$ NMR of compound 2 in DMSO- $\mathrm{d}_{6}$.

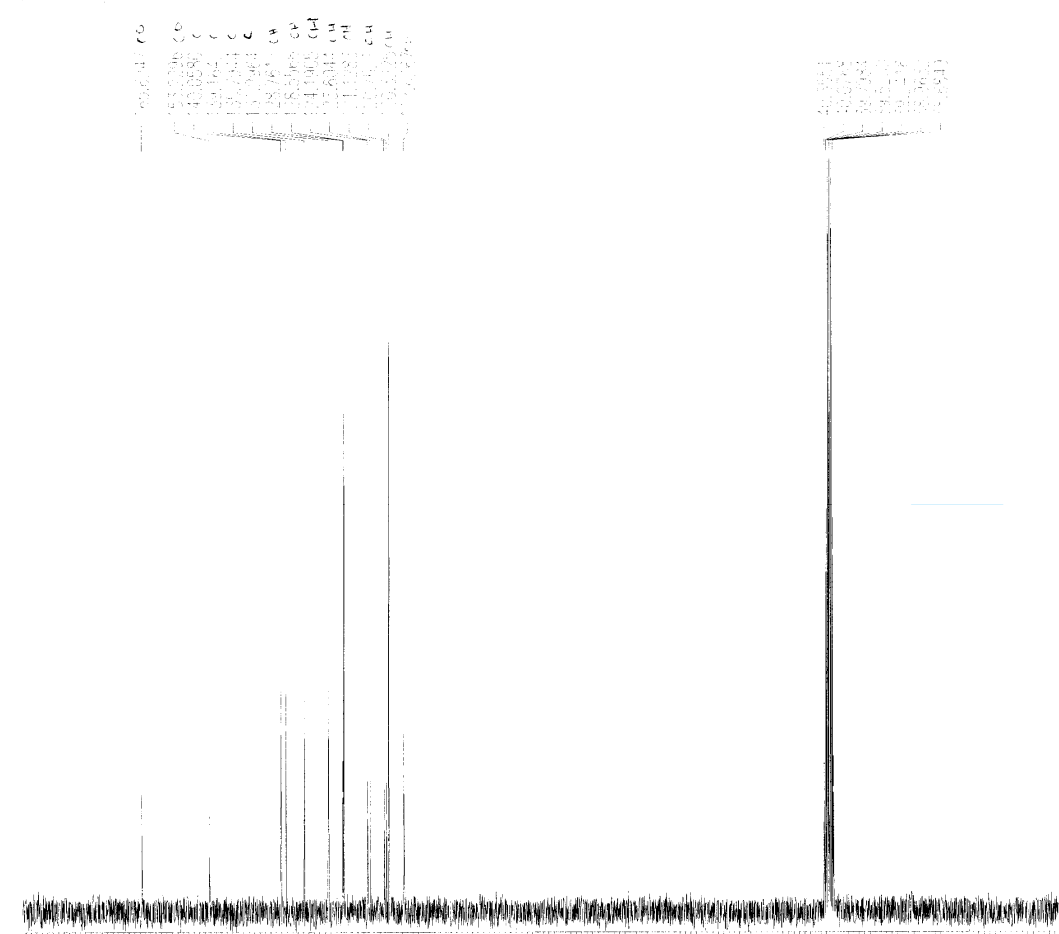

Figure $\mathrm{S} 5{ }^{13} \mathrm{C}$ NMR of compound 2 in DMSO- $\mathrm{d}_{6}$. 
Figure S6 ${ }^{13} \mathrm{C}$ DEPT NMR of compound 2 in DMSO-d $\mathrm{d}_{6}$

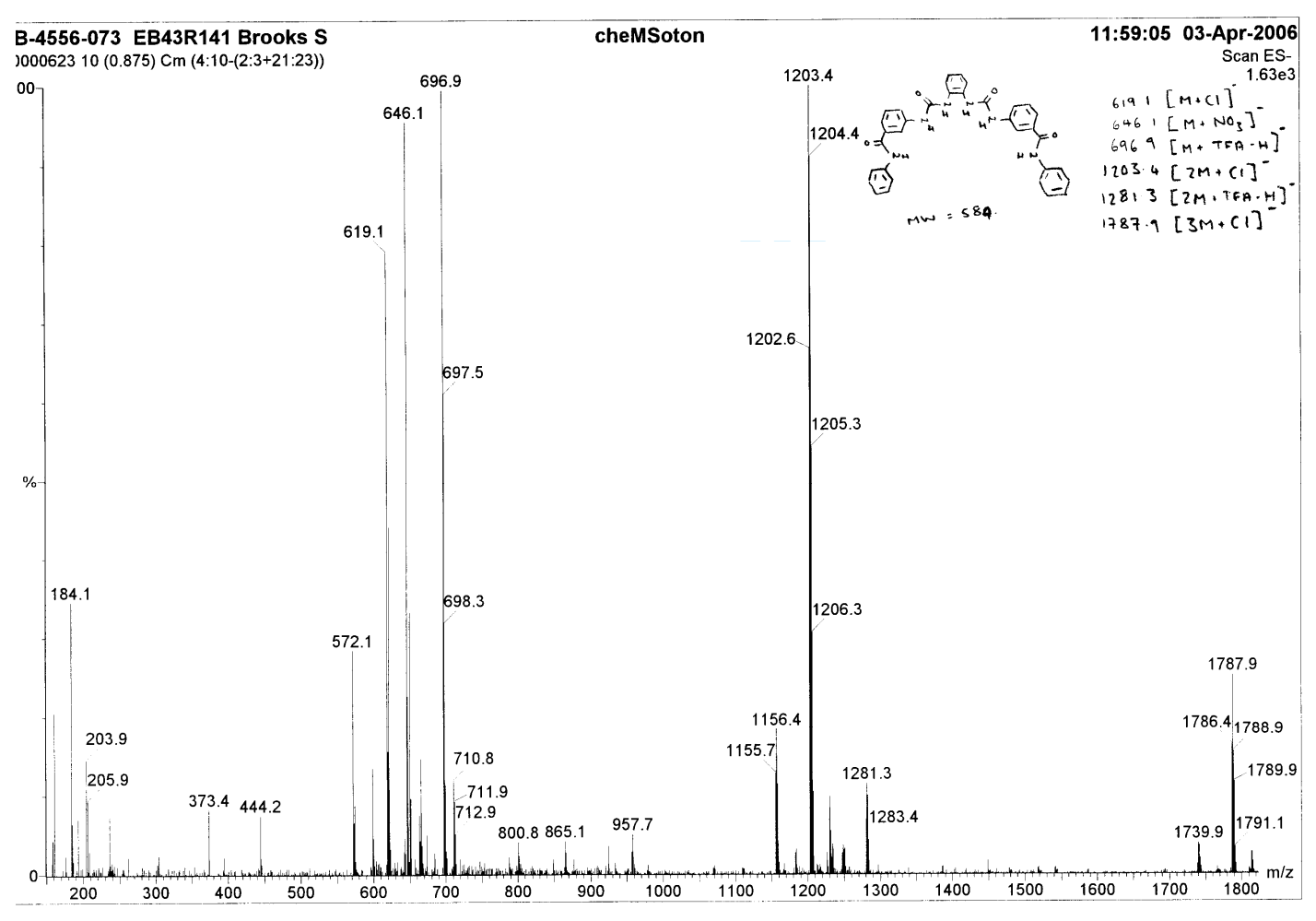

Figure S7 ES- MS of compound 2 in DMSO- $\mathrm{d}_{6}$. 


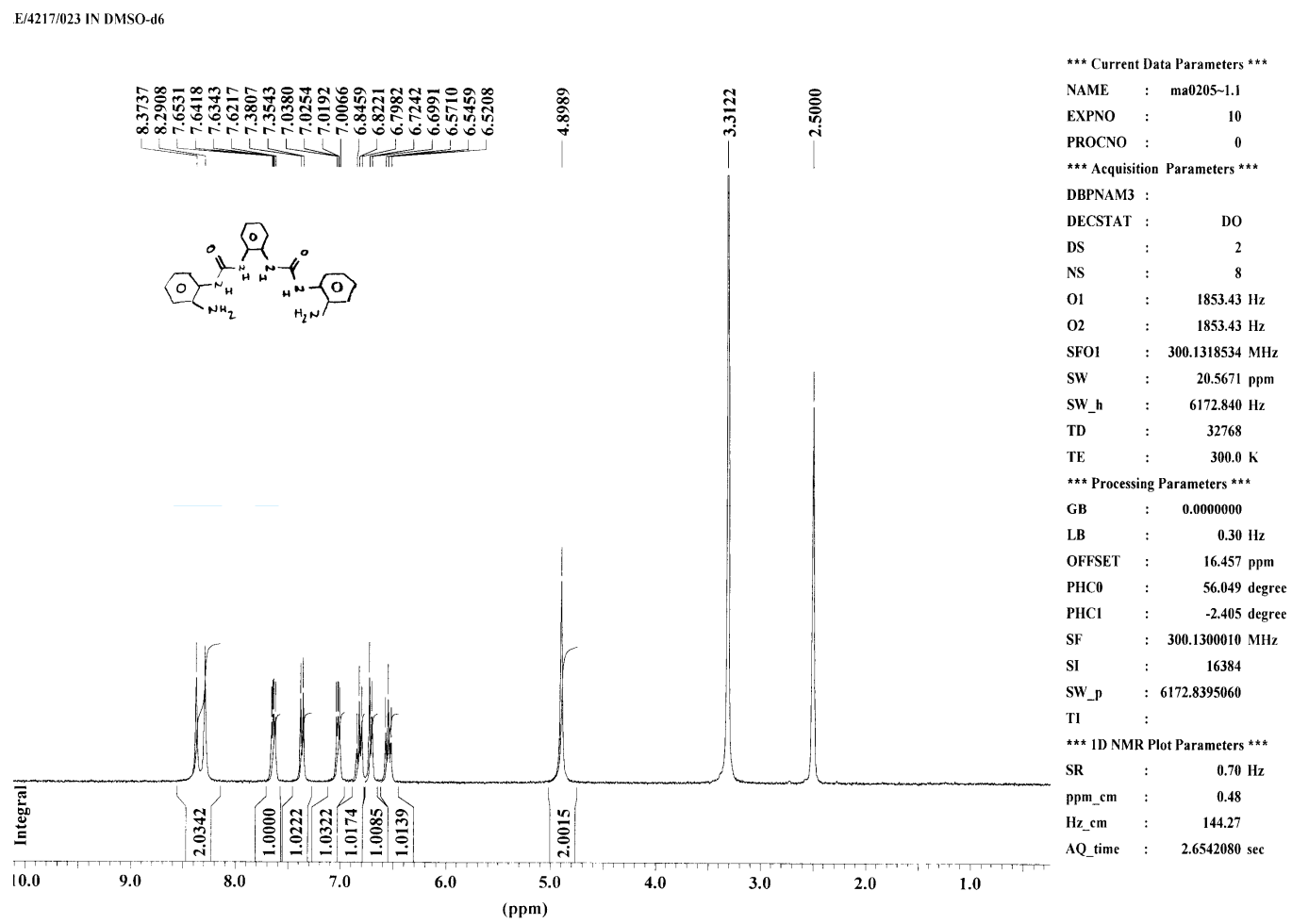

Figure S8 ${ }^{1} \mathrm{H}$ NMR of compound 6 in DMSO- $\mathrm{d}_{6}$

32
33
34
35
36
37
38
39
40
41
42
43
4
45
46
4
48
49
50
51
52
53
54
55
56
57
58
59
60

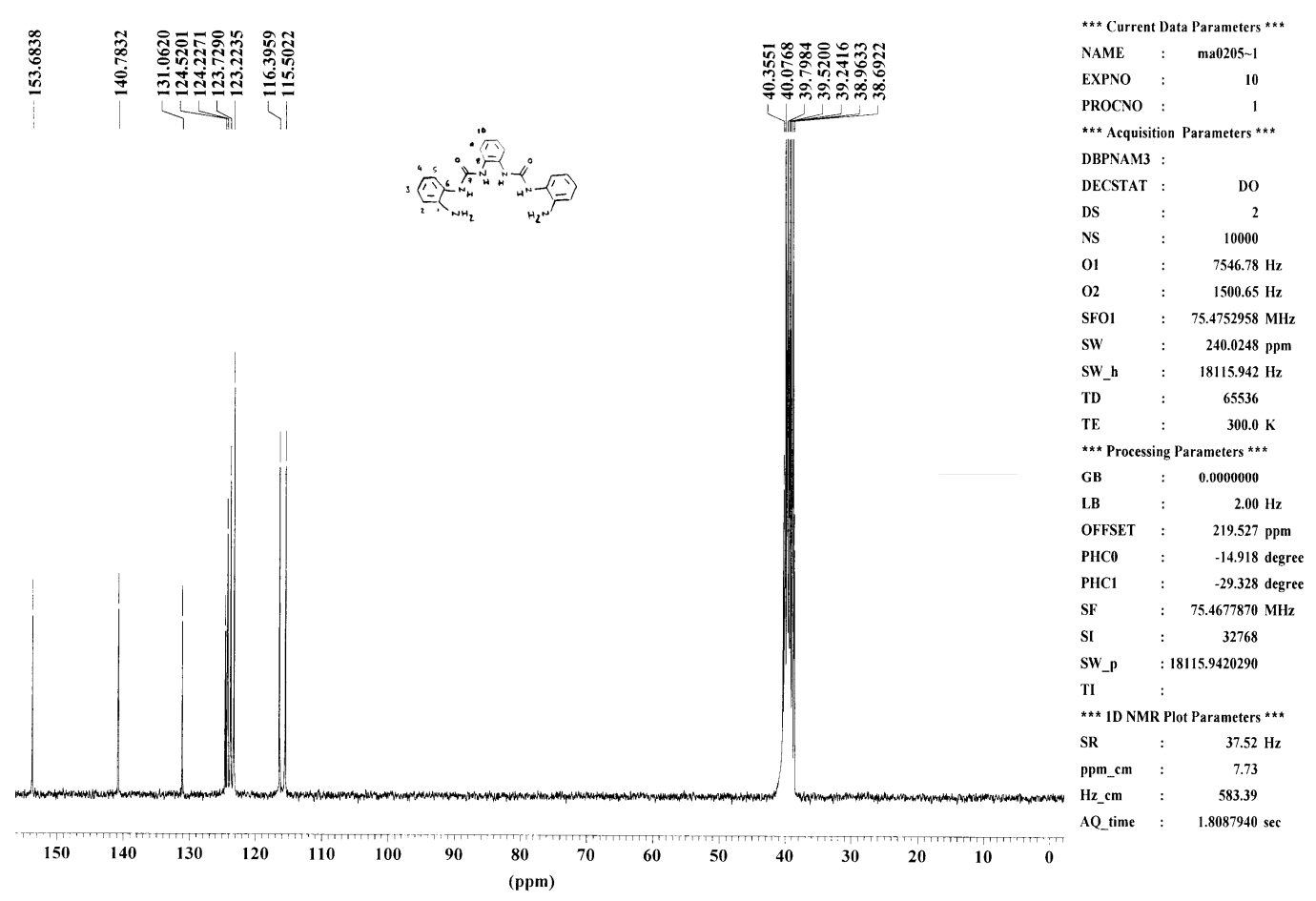

Figure S9 ${ }^{13} \mathrm{C}$ NMR of compound 6 in DMSO- $\mathrm{d}_{6}$ 


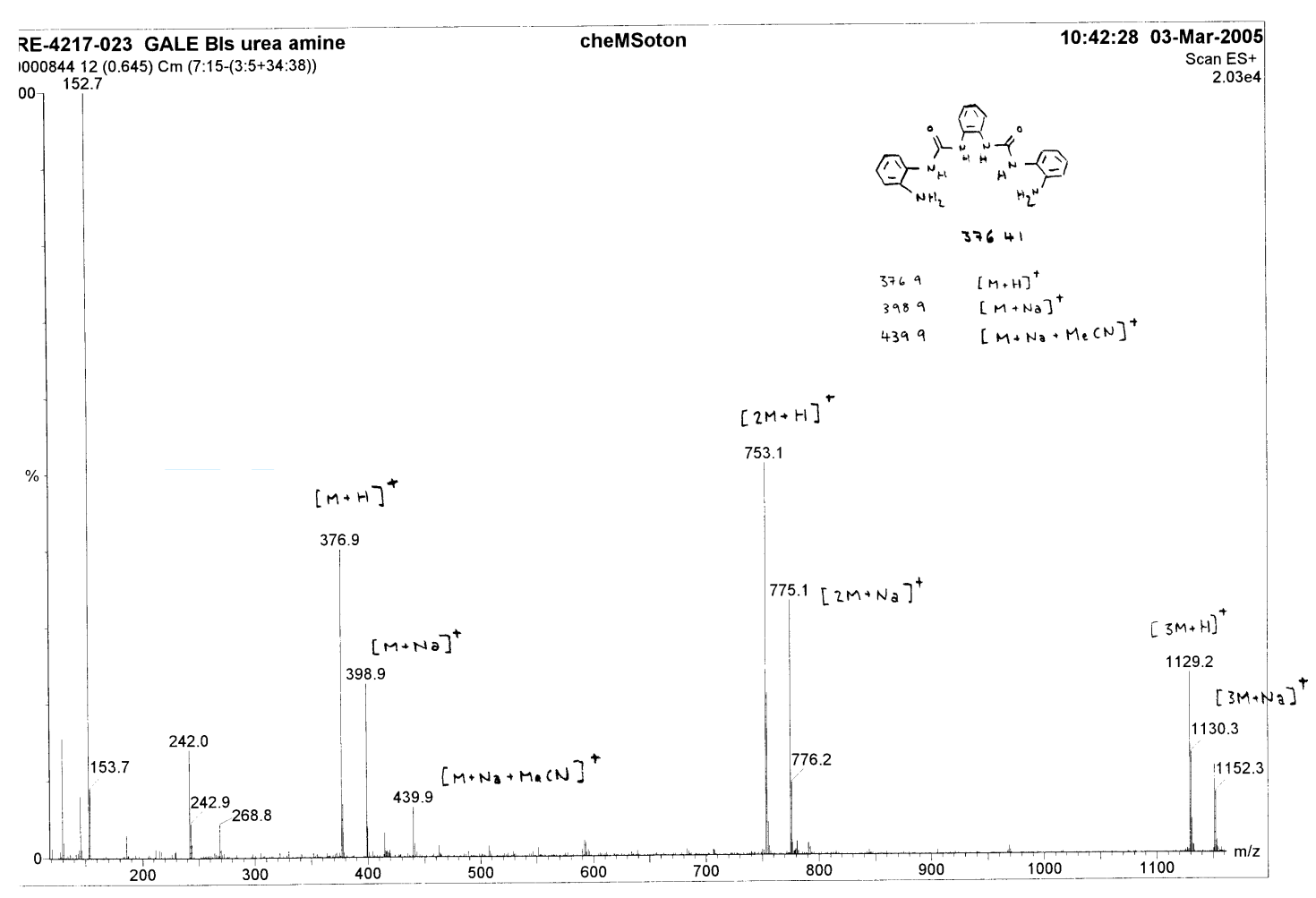

Figure S10 ES+ MS of compound 6

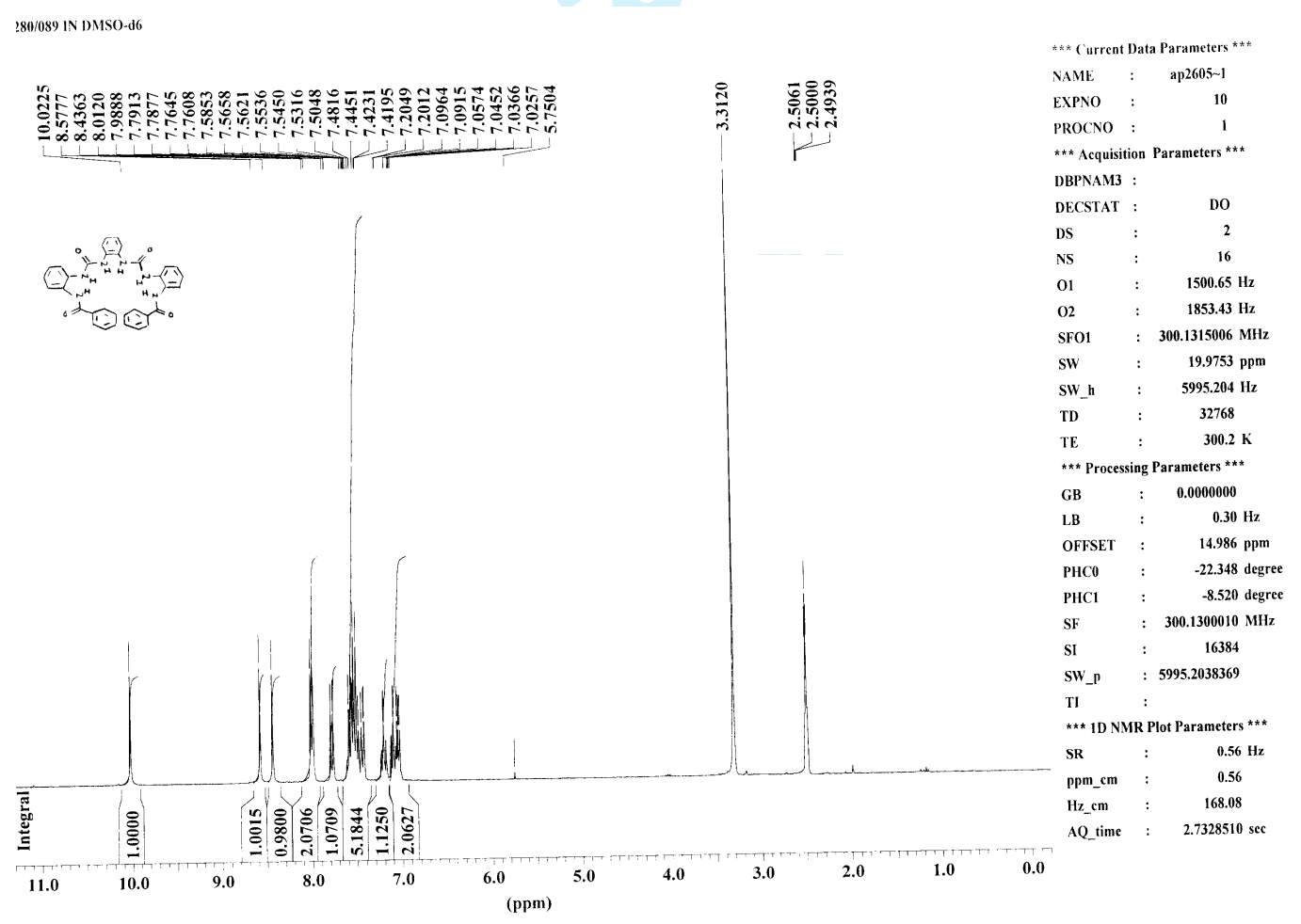

Figure $\mathrm{S} 11{ }^{1} \mathrm{H}$ NMR of compound 3 in DMSO-d 


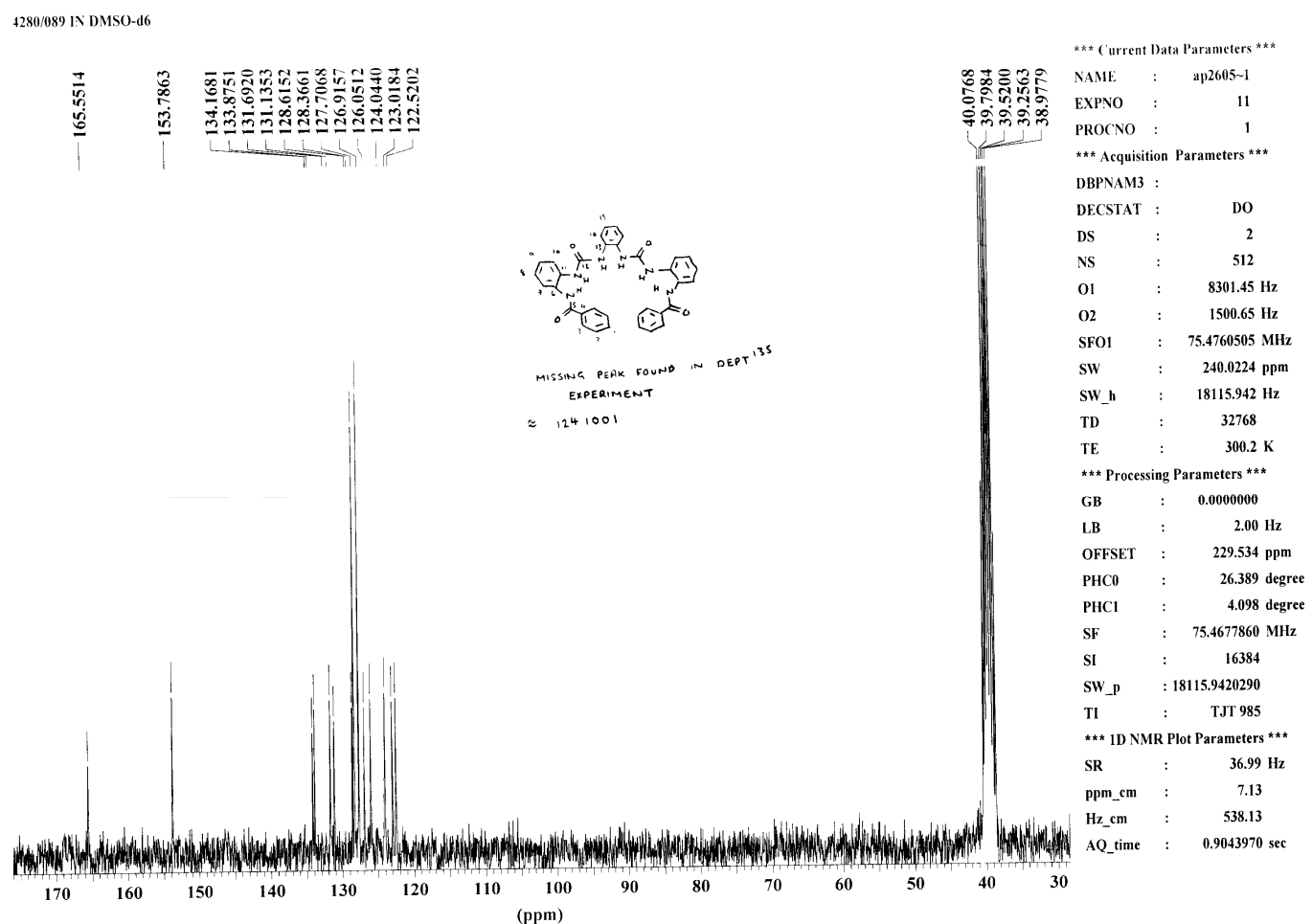

Figure $\mathrm{S} 12{ }^{13} \mathrm{C}$ NMR of compound 3 in DMSO- $\mathrm{d}_{6}$

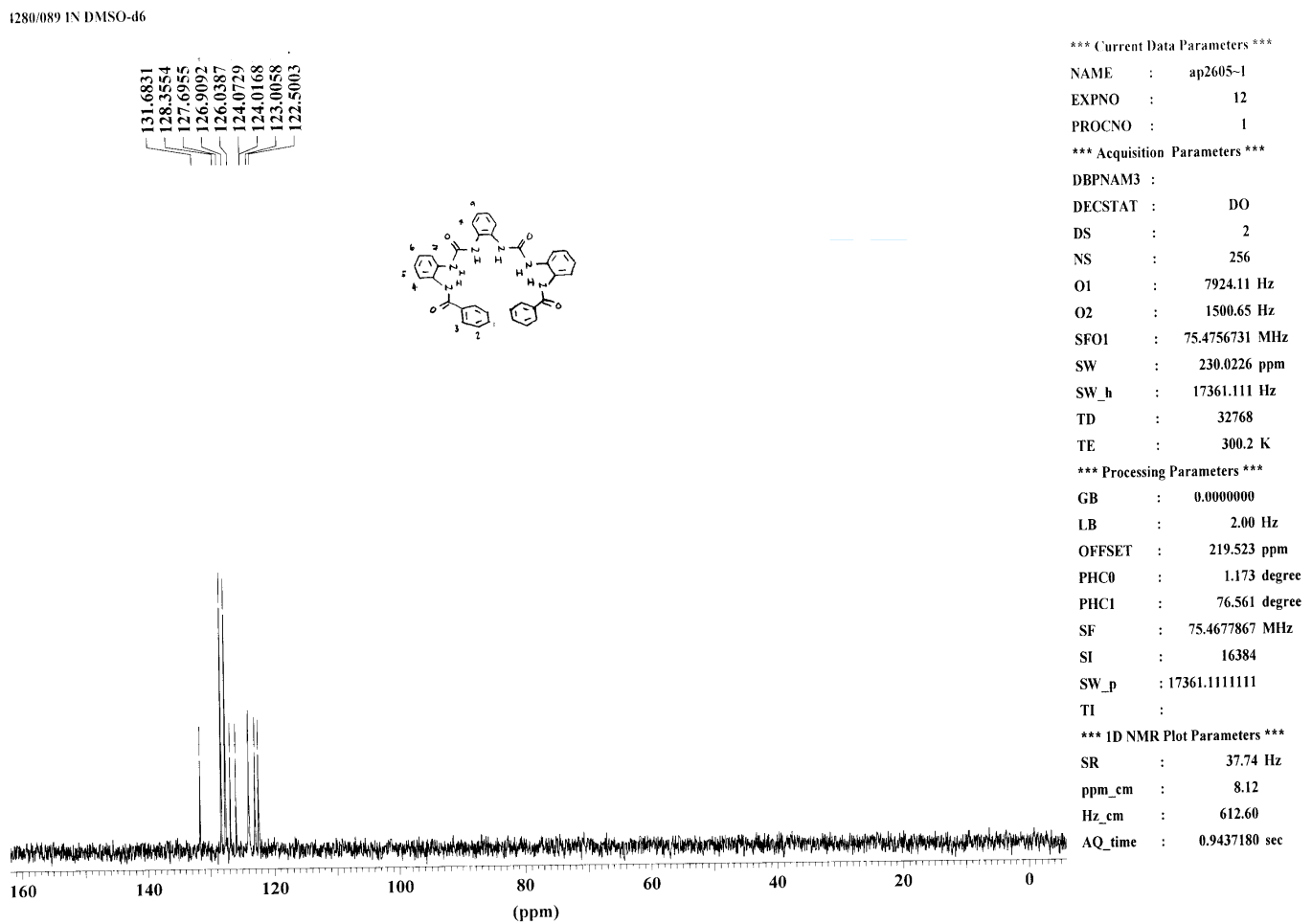

Figure $\mathrm{S} 13{ }^{13} \mathrm{C}$ DEPT NMR of compound 3 in DMSO-d 6 


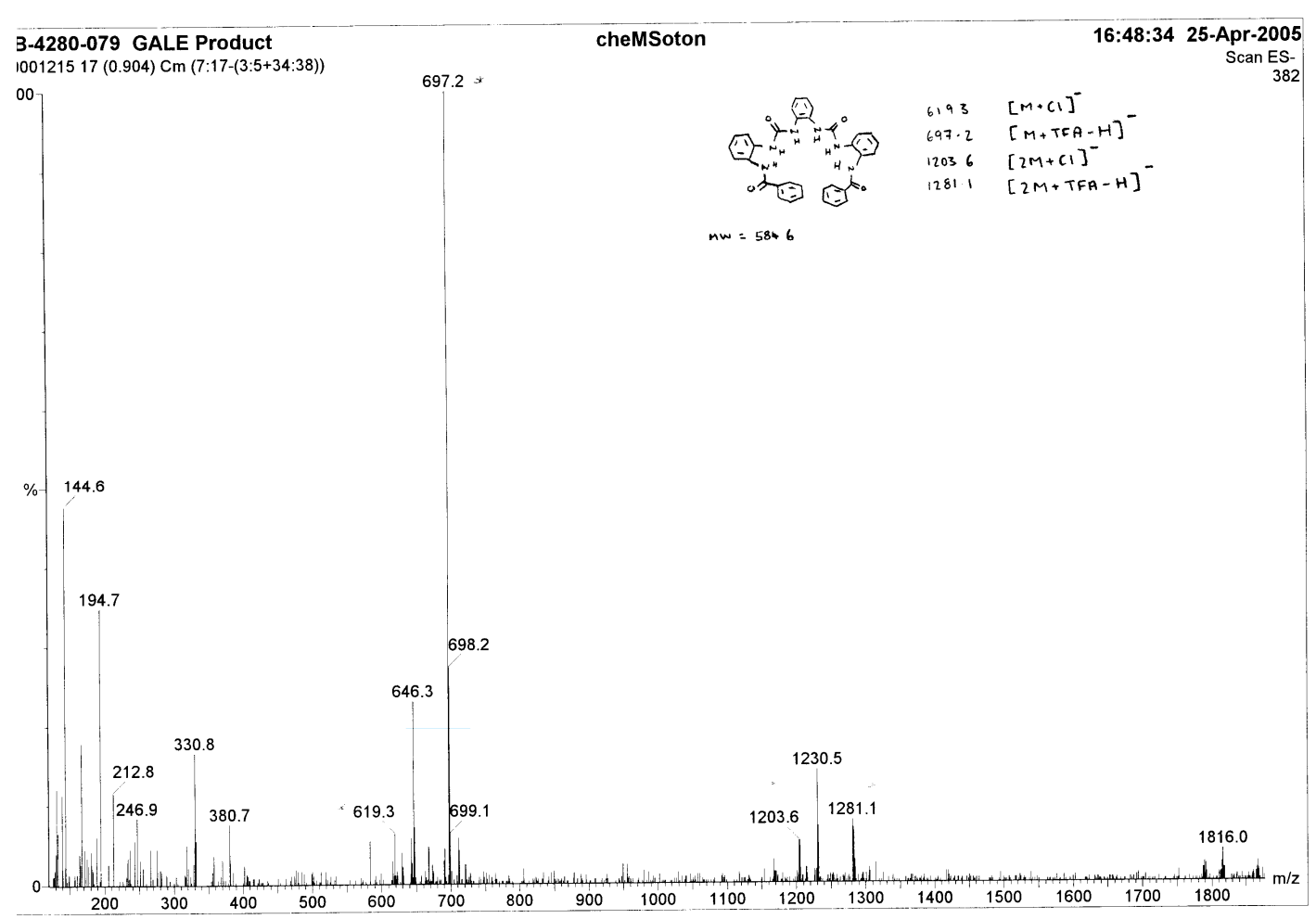

Figure S14 ES- MS of compound 3

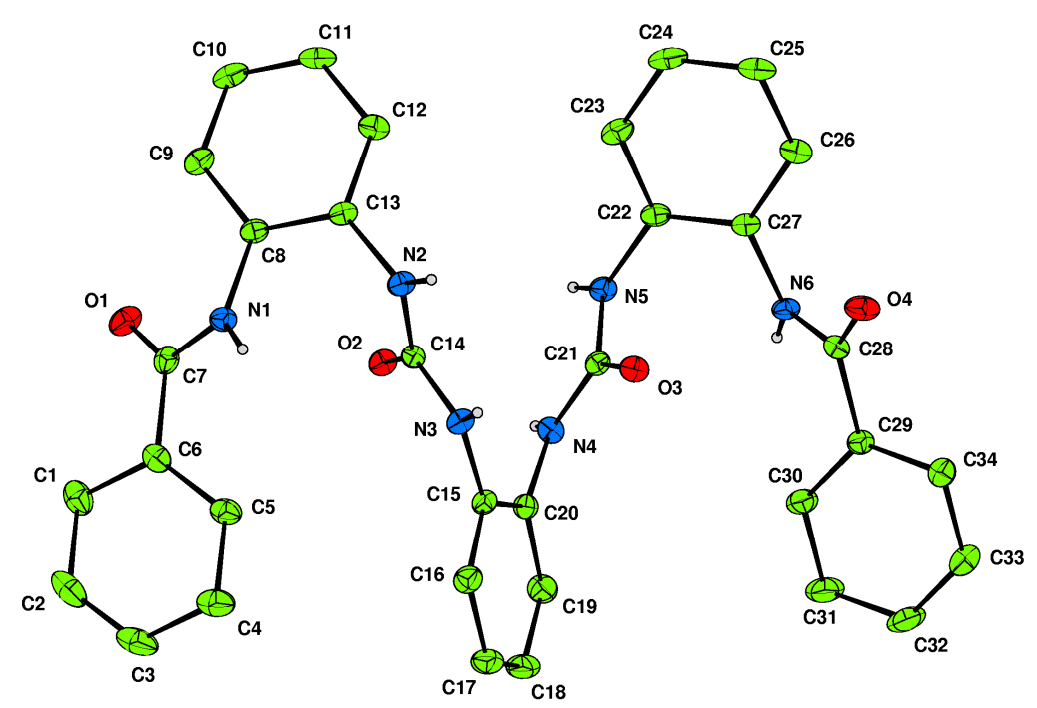

Figure S15 The X-ray crystal structure of compound 3. Thermal ellipsoids are drawn at the $35 \%$ probability level. 


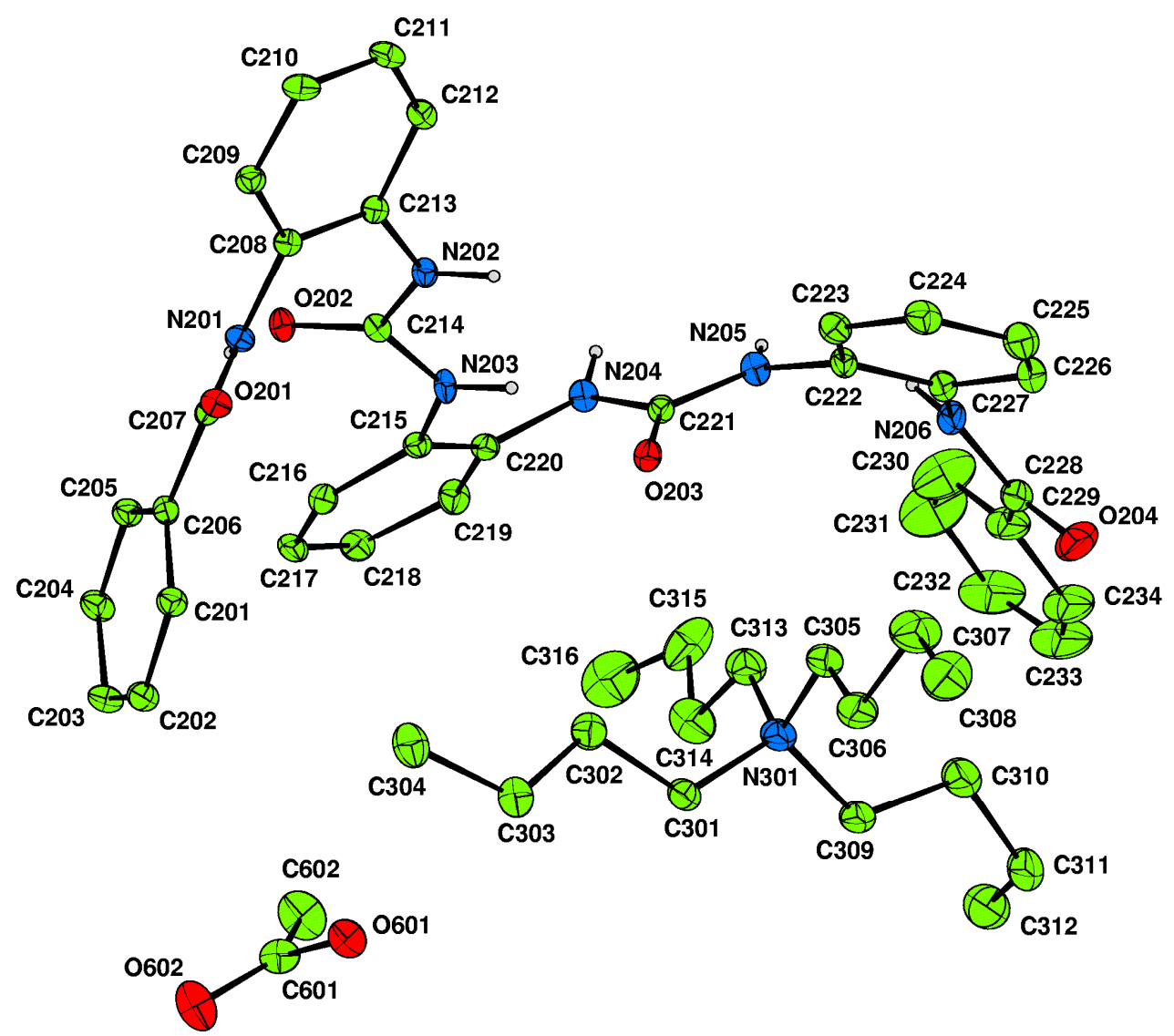

Figure S16 Half of the asymmetric unit (the other half is labelled in a similar fashion) in the TBA acetate complex of $\mathbf{3}$, thermal ellipsoids drawn at the $30 \%$ probability level. 

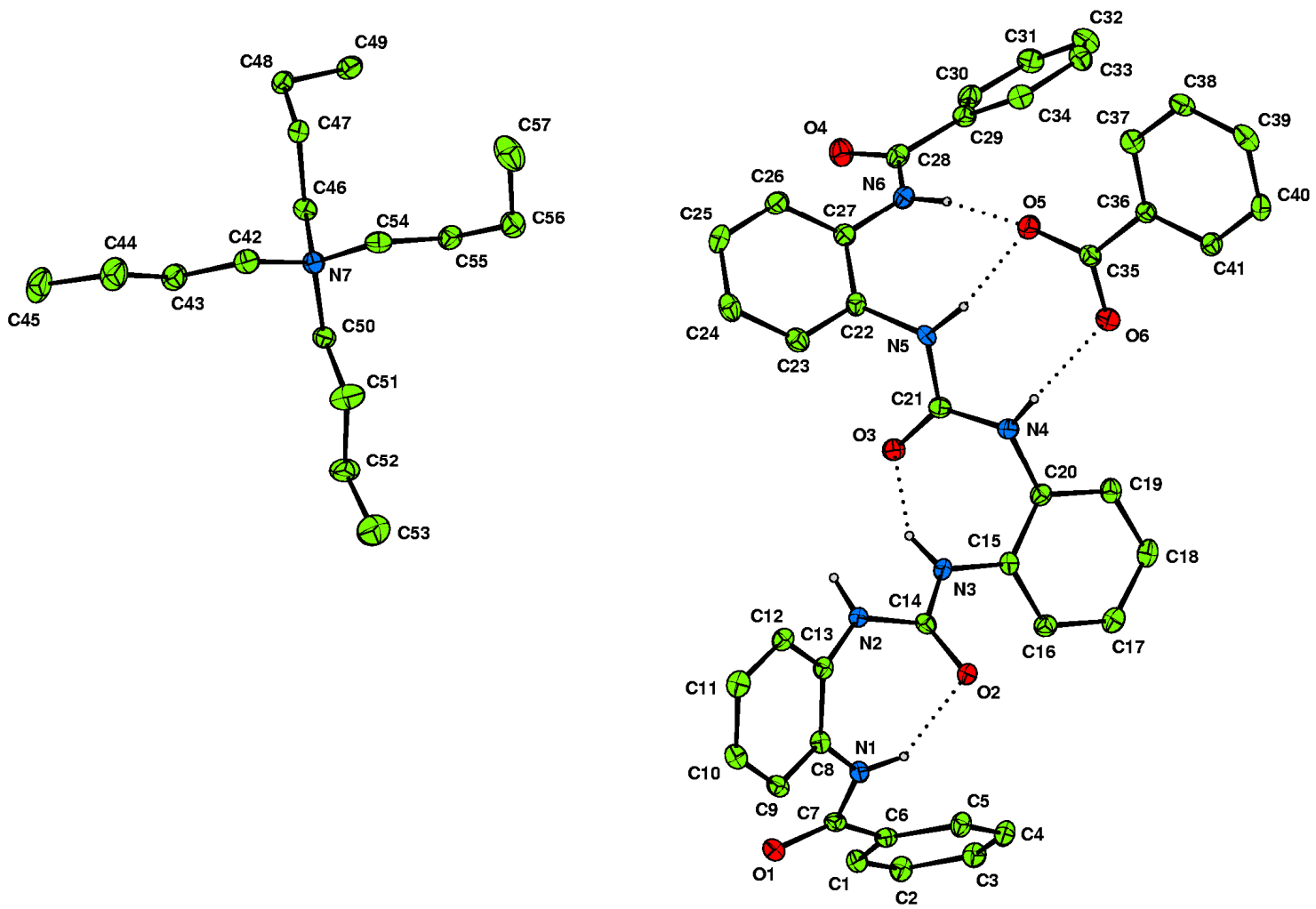

Figure S17 X-ray crystal structure of the TBA benzoate complex of $\mathbf{3}$. Thermal ellipsoids drawn at the $30 \%$ probability level. 
Figure S18 Compound 3 in DMSO- $d_{6} / 0.5 \%$ water.

Acetate.

$$
\begin{aligned}
& \mathrm{K}_{1}=6008 \quad \mathrm{~K}_{2}=<10 \\
& \mathrm{~K}_{12}=55230 \\
& \text { Error }=2.2 \& 3.2 \%
\end{aligned}
$$

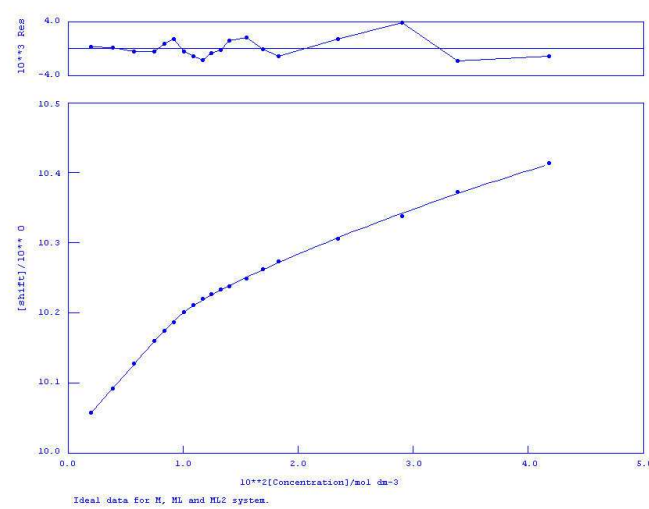

Chloride.

$\mathrm{K}_{\mathrm{a}}=17$

Error $=4.7 \%$

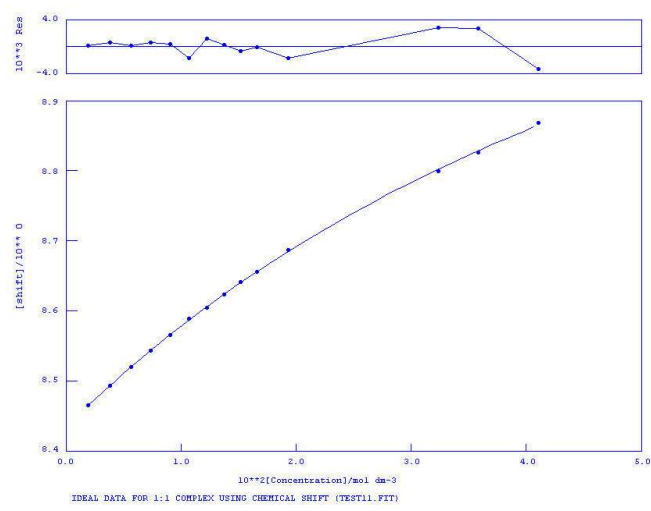

Benzoate.

$$
\begin{aligned}
& \mathrm{K}_{1}=10110 \quad \mathrm{~K}_{2}=<10 \\
& \mathrm{~K}_{12}=16554 \\
& \text { Error }=3.4 \% \text { \& } 12.5 \%
\end{aligned}
$$

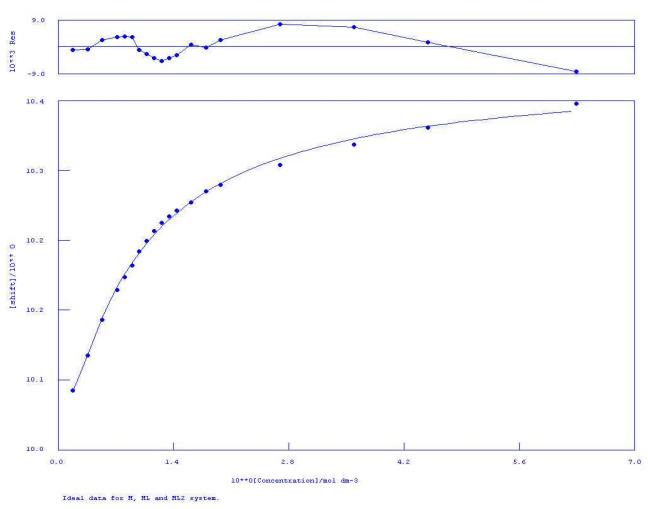

Dihydrogen Phosphate.

$$
\begin{aligned}
& K_{1}=7777 \quad K_{2}=24 \\
& K_{12}=185149 \\
& \text { Error }=5.7 \& 4.0 \%
\end{aligned}
$$

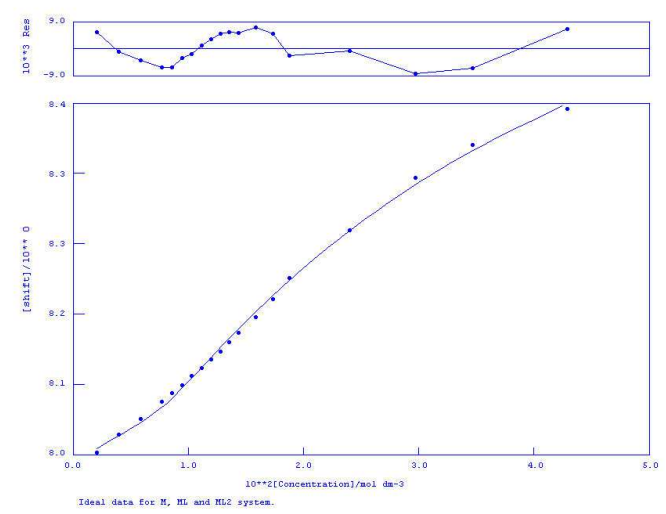


Figure S19 Compound 2 in DMSO- $d_{6} / 0.5 \%$ water.

Acetate.

$\mathrm{K}_{\mathrm{a}}=3199$

Error $=7.2 \%$

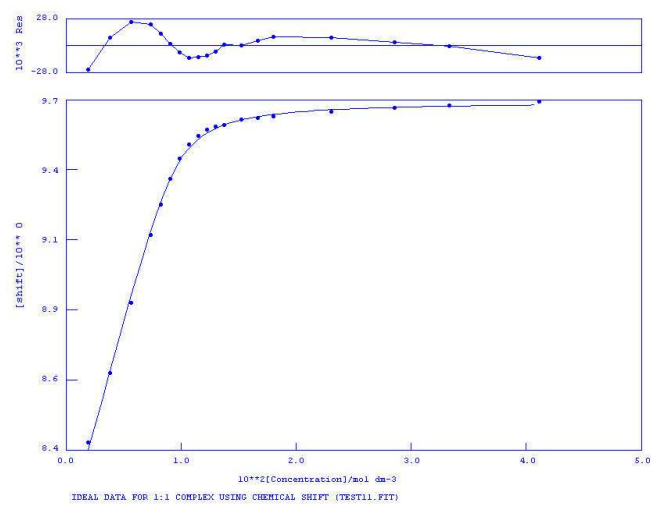

Chloride.

$\mathrm{K}_{\mathrm{a}}=52$

Error $=1.0 \%$

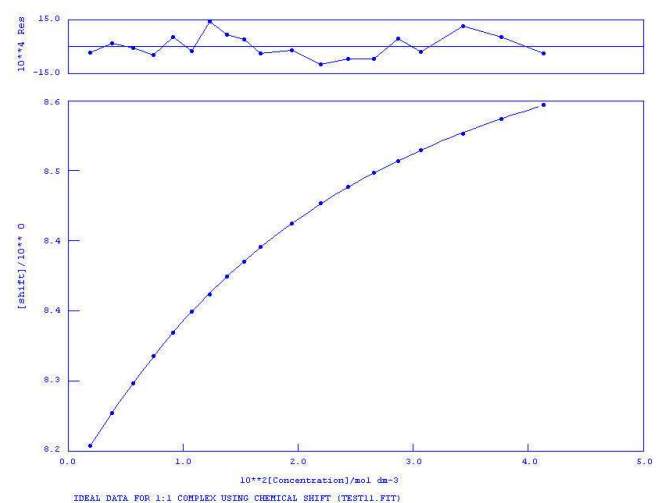

Hydrogen Sulfate.

$\mathrm{K}_{\mathrm{a}}=12$

Error $=10.8 \%$
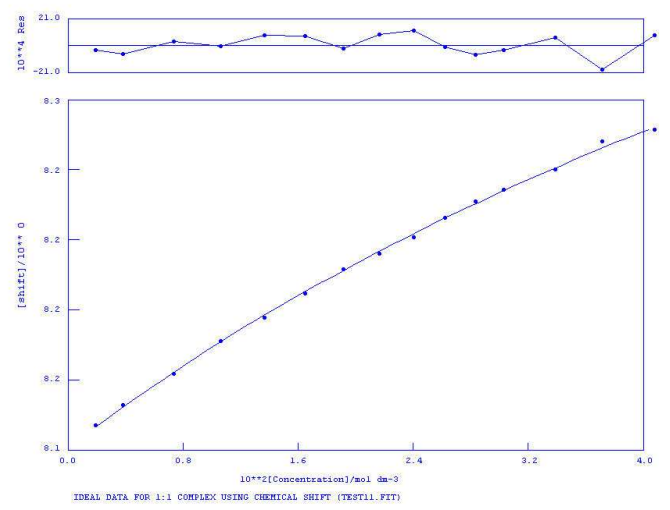

Benzoate.

$\mathrm{K}_{\mathrm{a}}=974$

Error $=7.2 \%$

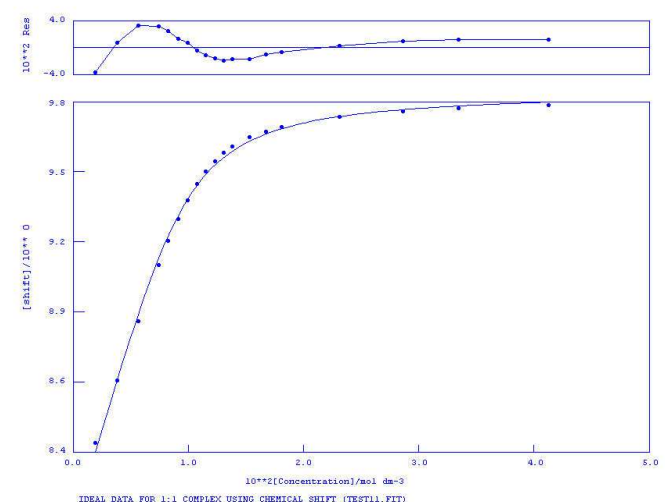

Dihydrogen Phosphate.

$\mathrm{K}_{\mathrm{a}}=2289$

Error $=11.8 \%$

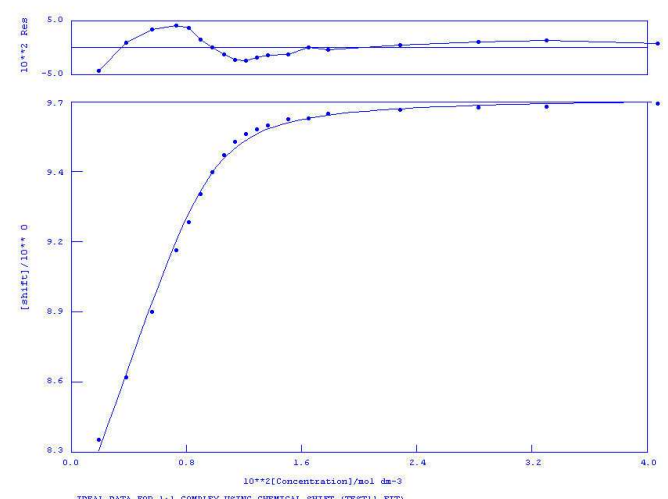


